\title{
Targeting Tumor-Associated Macrophages in Cancer Immunotherapy
}

\author{
Amy J. Petty ${ }^{1}{ }^{\circledR}$, Dwight H. Owen ${ }^{2}$, Yiping Yang ${ }^{3}$ and Xiaopei Huang ${ }^{3, *}$ \\ 1 Department of Medicine, Duke University Medical Center, Durham, NC 27710, USA; amy.petty@duke.edu \\ 2 Division of Medical Oncology, Department of Internal Medicine, College of Medicine and OSU \\ Comprehensive Cancer Center, The Ohio State University, Columbus, OH 43210, USA; \\ Dwight.owen@osumc.edu \\ 3 Division of Hematology, Department of Internal Medicine, College of Medicine and OSU Comprehensive \\ Cancer Center, The Ohio State University, Columbus, OH 43210, USA; Yiping.yang2@osumc.edu \\ * Correspondence: Xiaopei.huang@osumc.edu
}

Citation: Petty, A.J.; Owen, D.H.; Yang, Y.; Huang, X. Targeting Tumor-Associated Macrophages in Cancer Immunotherapy. Cancers 2021, 13, 5318. https://doi.org/10.3390/ cancers13215318

Academic Editor: Mary Poupot

Received: 15 September 2021

Accepted: 19 October 2021

Published: 22 October 2021

Publisher's Note: MDPI stays neutral with regard to jurisdictional claims in published maps and institutional affiliations.

Copyright: (c) 2021 by the authors. Licensee MDPI, Basel, Switzerland. This article is an open access article distributed under the terms and conditions of the Creative Commons Attribution (CC BY) license (https:// creativecommons.org/licenses/by/ $4.0 /)$.
Simple Summary: Tumor-associated macrophages (TAMs) coinhabit the tumor microenvironment with cancer, immune, and stromal cells. They undermine the immune system and facilitate tumor growth and metastasis. In this review, we discussed current understanding of TAMs functions, and strategies harnessing the knowledge gained from recent research to develop innovative cancer treatments. We summarized pre-clinical/clinical studies targeting TAMs with small molecule inhibitors or antibodies alone or combined with chemotherapy/immunotherapy, evaluated the efficacy of these therapies, and discussed mechanisms of actions.

Abstract: Tumor-associated macrophages (TAMs) represent the most abundant leukocyte population in most solid tumors and are greatly influenced by the tumor microenvironment. More importantly, these macrophages can promote tumor growth and metastasis through interactions with other cell populations within the tumor milieu and have been associated with poor outcomes in multiple tumors. In this review, we examine how the tumor microenvironment facilitates the polarization of TAMs. Additionally, we evaluate the mechanisms by which TAMs promote tumor angiogenesis, induce tumor invasion and metastasis, enhance chemotherapeutic resistance, and foster immune evasion. Lastly, we focus on therapeutic strategies that target TAMs in the treatments of cancer, including reducing monocyte recruitment, depleting or reprogramming TAMs, and targeting inhibitory molecules to increase TAM-mediated phagocytosis.

Keywords: tumor-associated macrophages (TAM); tumor microenvironment; immunotherapy; checkpoint inhibitor; cancer

\section{Introduction}

Macrophages represent one of the largest leukocyte populations within the tumor stroma and play an important role in neoplastic progression. These macrophages, also known as tumor-associated macrophages (TAMs), can promote tumor cell growth through a variety of mechanisms including enhanced angiogenesis and chemotherapy resistance as well as by suppressing anti-tumor immunity [1,2]. Increased infiltration of macrophages is correlated with poor clinical prognosis in many cancers [2]. This review focuses on the role of TAMs in tumor progression and immunotherapeutic options to target this population.

\section{Macrophage and TAMs}

Macrophages play important roles in the human body, ranging from tissue homeostasis to protection against pathogenic infections. Various environmental signals can activate a broad array of intracellular transcriptional networks in macrophages resulting in the polarization of functions. The M1/M2 polarization states of macrophages include the 
classically activated M1 macrophages and the alternatively activated M2 macrophages [3]. Though these states mirror the Thelper 1 (Th1)-Th2 states of T cells, the M1/M2 phenotypes are not stably differentiated in the same way as Th1 and Th2 cells. Rather, macrophages in human patients as well as mouse models can exhibit phenotypes in a spectrum with two extremes defined by M1 and M2 [4]. Interferon- $\gamma$ (IFN- $\gamma$ ), microbial products (e.g., lipopolysaccharides/LPS), granulocyte-macrophage colony stimulating factor (GM-CSF), and Th1 cytokines such as interleukin-12 (IL-12) activate M1-polarization of macrophages, which are involved in innate host defense and pro-inflammatory functions by expressing high levels of cytokines such as IL-1, IL-6, and IL-12; tumor necrosis factor (TNF); surface receptors such as Fcy-RI, II, and IIIA; and reactive oxygen/nitrogen species (ROS/RNS) [3]. In contrast, M2 macrophages are activated by IL-4, IL-13, IL-10, and macrophage colonystimulating factor (M-CSF/CSF-1) and in turn produce large amounts of anti-inflammatory, pro-fibrotic, and pro-angiogenic cytokines such as IL-10, transforming growth factorbeta (TGF- $\beta$ ), vascular endothelial growth factor (VEGF), and matrix metalloproteins (MMPs) [3,5]. M1 and M2 polarized macrophages both play an important role in tissue homeostasis and tissue recovery with M1 macrophages infiltrating after injury to clean the wound of bacteria, debris, and dead cells, and M2 follows to promote anti-inflammatory effects and restoration of local structure and vasculature through the actions of associated cytokines. In chronic wounds, pro-inflammatory M1 macrophages persist without transitioning to M2 macrophages, which is a necessary step in tissue repair, ultimately resulting in impairment in wound healing [6]. Although these cytokines and molecules can be beneficial in normal tissue healing and remodeling, they may enhance tumor progression within the tumor microenvironment. Furthermore, M1 and M2 macrophages are associated with different chemokine profiles. M1 macrophages produce high levels of CXCL9, CXCL10, and CCL5 that can promote cytotoxic T cell functions with host defense and in tumor. On the other hand, M2-associated chemokines including CCL17 and CCL22 help recruit regulatory $\mathrm{T}$ cells $\left(\mathrm{T}_{\mathrm{reg}}\right)$ that can further dampen host immune responses at the tumor site [5]. Interestingly, CCL2 has been implicated in both M1 and M2 polarization. There are observations that direct stimulation of cells with CCL2 favored M1 macrophage polarization, and that CCL2 or CCR2 knockout mice showed decreased M1 markers including iNOS, IL-12 and TNF- $\alpha$ compared to wildtype unstimulated bone marrow derived macrophages [7-9]. However, in cancer, strong evidence indicates that CCL2-CCR2 blockade suppresses M2 polarization and enhances $\mathrm{T}$ cell cytotoxicity [10]. There are ongoing debates about the dichotomous and highly context specific roles of CCL2 in benign vs. malignant inflammatory processes. Further investigation in this area is needed to guide the development of therapies targeting CCL2-CCR2 in cancer.

Though often considered interchangeable with M2-macrophages, TAMs should be considered a separate group of pro-tumoral macrophages due to their distinct transcriptional and phenotypic characteristics [11]. The simplified M1-M2 dichotomy does not consider a variety of factors that can potentially influence TAM functions, including location, type, and stage of the tumor. It has been a challenge to identify specific subgroups of TAMs with overlapping features based on one set of specific markers due to intrinsic heterogeneity of the macrophage population. Additionally, it remains unanswered whether the heterogeneity observed in TAMs stem from distinct precursors or variance in microenvironmental stimuli during tumor development.

In addition to difficulties encountered in classifying TAMs in vivo, the origin of TAMs also remains controversial. It has been hypothesized that TAMs are infiltrating monocytes recruited from circulation via chemotaxis. Studies have shown that TAMs are replaced by circulating $\mathrm{Ly} 6 \mathrm{C}^{\text {hi }} \mathrm{CCR} 2^{+}$monocytes in various tumor models [12-16]. Circulating inflammatory Ly6 $\mathrm{Ch}^{\text {hi }} \mathrm{CD} 11 \mathrm{c}^{-} \mathrm{MHCII}{ }^{-} \mathrm{CD} 11 \mathrm{~b}^{\text {hi }} \mathrm{CCR} 2^{+}$monocytes, derived from $\mathrm{BM}$ hematopoietic stem cells are recruited to tumor sites and later differentiated into TAMs. A study by Franklin RA et al., using a PyMT mammary tumor model suggested a key role of Notch signaling pathway in TAM differentiation [13]. In addition, using mouse models that enable BM-derived monocytes tracking, Shand et al. showed that 
tumor-associated macrophages were derived and rapidly replenished from the BM in tumor-bearing mice [17]. Others have shown that tissue-resident macrophages may play an equally important role in contributing to the TAM population. In non-small cell lung cancer (NSCLC), tissue resident macrophages provide a pro-tumorigenic niche to early NSCLC cells [18]. Zhu et al. identified both inflammatory monocytes and tissue-resident macrophages as sources of TAMs with monocyte-derived TAMs playing more important roles in antigen presentation and embryonic-derived TAMs exhibiting a more pro-fibrotic profile [19]. Further studies are needed to examine the potentially different roles of monocytic vs. embryonic-derived TAMs in tumor development and progression. Nonetheless, TAM expansion and polarization within the tumor microenvironment requires myeloid cell recruitment and factors that drive the immunosuppressive polarization of TAM. Increased levels of CCL2, CSF1, and VEGF-A are correlated with macrophage accumulation at the tumor site in a wide spectrum of human cancers, including those of breast, prostate, ovarian and lung [20-22]. Once recruited to the primary tumor site, various signaling pathways, including JAK/Stat, PI3K/Akt, and hedgehog orchestrate the polarization under the influence of various tumor-derived or stroma-derived factors [23,24]. IL-4 and IL-13, synthesized by $\mathrm{CD} 4^{+} \mathrm{T}$ cells and/or tumor cells act on infiltrating macrophages through intracellular Stat6 and PI3K signaling to promote an immunosuppressive TAM phenotype while IL-10 produced by regulatory $\mathrm{T}$ cells $\left(\mathrm{T}_{\text {reg }}\right)$ also participates in the activation of the TAM phenotype via the actions of Stat3. Other cytokines secreted by the tumor cells, including CSF1 and TGF- $\beta$ also strongly promote M2-polarization of TAMs [23,25]. Lactic acid, a tumor cell-derived aerobic glycolysis byproduct induces TAM functional polarization through the action of hypoxia inducible factor $1 \alpha$ (HIF-1 $\alpha$ ) resulting in subsequent promotion of tumorigenesis [26]. In our laboratory, we demonstrated that tumor-derived sonic hedgehog (Shh) ligand promotes M2-polarization of TAMs to suppress CD8 ${ }^{+} \mathrm{T}$ cell infiltration through downregulation of CXCL9 and CXCL10 and limit effector T cell functions by upregulating programmed death ligand-1 (PD-L1) expression on TAMs [24,27]. However, TAM polarization is a dynamic process and demonstrates great functional and phenotypic diversity depending on the cancer type and tumor stage [2]. Understanding the origin of macrophages within the tumor stroma in different types and stages of cancer, and the mechanisms of recruitment, retention, and differentiation is crucial for the design of rational strategies to effectively targeting this population of cells in cancer immunotherapy.

\section{The Functions of Tumor-Associated Macrophages}

TAMs within the tumor microenvironment play a pivotal role in promoting tumorigenesis and metastasis via both non-immune and immune mechanisms, leading to poor clinical outcome in patients with various types of solid tumors and hematologic malignancies $[28,29]$. The critical role of TAM in promoting tumor cell proliferation, angiogenesis, metastasis, and immunosuppression within the TME are discussed below and illustrated in Figure 1.

\subsection{Augmenting Tumor Proliferation}

TAMs not only provide structural support within the tumor stroma but can also facilitate cancer initiation by secreting signal molecules, including growth factors, such as epithelial growth factor (EGF), platelet-derived growth factor (PDGF), TGF- $\beta$, hepatocyte growth factor (HGF), and basic fibroblast growth factor (bFGF) among other cytokines and chemokines [30]. Additionally, Tong et al. reported that TAM-derived CXCL8 decreases ER $\alpha$ expression, resulting in endometrial cancer progression [31]. In pancreatic ductal adenocarcinoma, TAM-derived IL-1 $\beta$ prevents expression of 15-hydroxyprostaglandin dehydrogenase (15-PGDH) and low 15-PGDH is correlated with more advanced tumor stage and lymph node metastasis [32].

In addition to supporting tumor cell growth, TAMs have also been found to support cancer stem cells (CSCs), a group of cells within the tumor stroma that can proliferate indefinitely, resulting in tumor progression and increased resistance to cytotoxic therapy $[33,34]$. 
TNF- $\alpha$ released by TAMs triggers the expansion of a group of stem-like cancer cells via NF- $\kappa$ B signaling in a colon cancer while TAM-derived IL-6 promotes CSCs growth via Stat3 in human hepatocellular carcinoma [35,36]. Akt/mTOR signaling in renal cell carcinoma was also found to increase stem cell-like populations in the presence of TAMs [37]. Additionally, juxtacrine communications between CSCs and TAMs via the CD90 and Eph4A receptors sustain the CSC niche in breast cancer by activating Src and NF- $\kappa$ B [38]. Recent studies also demonstrated that TAM-derived milk fat globule-epidermal growth factor 8 (MFG-E8) favors CSC reservoir survival during chemotherapeutic treatments via activation of Sonic hedgehog and Stat3 pathways [39]. Yang et al. reported that gene signatures representing CSC properties (Sox-2, Oct-4, Nanog, AbcG2 and Sca-1) were found to be upregulated by TAMs via a paracrine EGFR/Stat3/Sox2 signaling pathway, resulting in increased drug efflux capacity and resistance to chemotherapy in murine breast cancer cells [40]. Not surprisingly, inhibiting CSF1R or CCR2 on TAMs arrests the proliferation of CSCs, resulting in improved chemotherapeutic responses in pancreatic carcinoma [41].

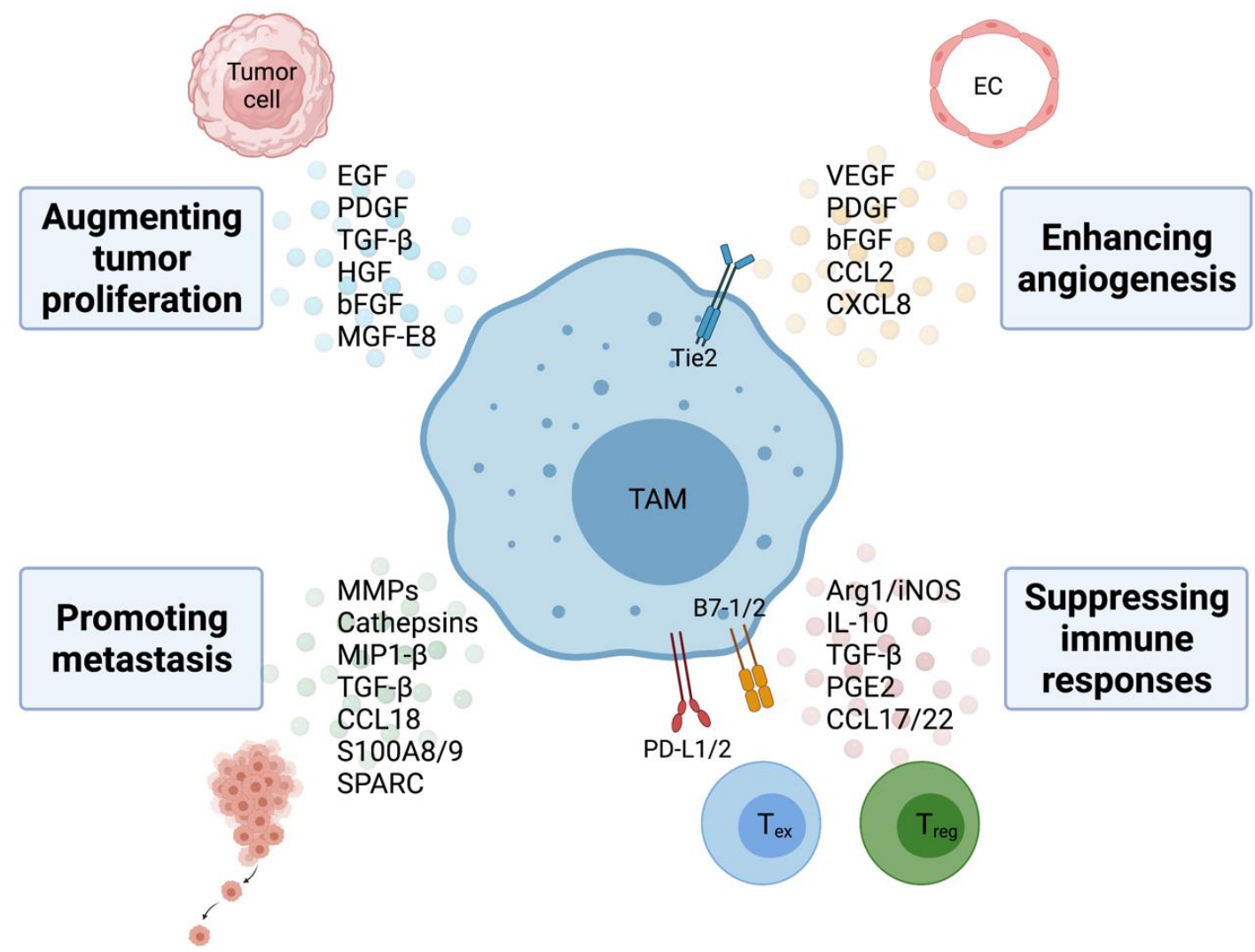

Figure 1. Functional roles of TAMs. TAMs can promote tumor progression through four main mechanisms: (1) augmenting tumor proliferation; (2) enhancing angiogenesis; (3) promoting metastasis; and (4) suppressing adaptive immune responses. Abbreviations: EGF-epithelial growth factor; PDGF-platelet-derived growth factor; TGF- $\beta$ - transforming growth factor beta; HGF-hepatocyte growth factor; bFGF-basic fibroblast growth factor, MGF-E8-milk fat globule-EGF factor 8; EC — endothelial cell; VEGF—vascular endothelial growth factor; CCL2-C motif chemokine ligand 2; CXCL8-C-X-C motif chemokine ligand 8; MMPs-matrix metalloproteases; MIP1- $\beta$-macrophage inflammatory protein 1 beta; CCL18 - C motif chemokine ligand 18; S100A8/9—S100 calcium binding protein A8/9; SPARC—secreted protein acidic and cysteine rich; Arg1—arginase 1; iNOS—inducible nitric oxide synthase; IL-10—interleukin 10; PGE2—prostaglandin E2; CCL17/22-C motif chemokine ligand 17/22; PD-L1/2 - programmed death ligand $\frac{1}{2} ; \mathrm{T}_{\mathrm{ex}}$ - exhausted $\mathrm{T}$ cell; $\mathrm{T}_{\text {reg }}$-regulatory $\mathrm{T}$ cell. Created with BioRender.com.

\subsection{Enhancing Angiogenesis}

Previous evidence has shown that TAMs are extensively involved in each step of the angiogenic process from degradation of the basement membrane through the production 
of matrix metalloproteinases (MMPs) and cathepsins to the secretion of proangiogenic growth factors such as VEGF, PDGF, bFGF, and chemokines CCL2 and CXCL8 that provide the vascular network critical for cancer cell growth and dissemination [42,43]. Additionally, VEGF and CCL2 also act as strong chemotactic factors for the infiltration and polarization of TAMs and increased expression of both is positively correlated with a high degree of tumor neovascularization in human invasive ductal breast carcinoma [44]. Therefore, TAMs play a critical role in tumor angiogenesis by working in concert with tumor-derived angiogenic factors.

Interestingly, a unique subset of $\mathrm{Tie}^{+}$macrophages have been shown to regulate angiogenic switch in the PyMT breast cancer model [45]. Hypoxia and CSF-1 upregulate Tie2 expression on TAMs and then the expression of angiopoietin 1 and 2, ligands for Tie2 on endothelial cells allows for the alignment of Tie ${ }^{+}$macrophage along the abluminal surface of blood vessels, resulting in macrophage-synthesized WNT7b targeting of vascular endothelial cells, their production of VEGF and ultimately activation of the angiogenic switch [46-48]. Hypoxia itself is also a potent regulator of the pro-angiogenic functions of TAMs via the transcription factor hypoxia-inducible factor 1- $\alpha$ (HIF-1 $\alpha$ ), which upregulates VEGF expression [49]. Lastly, Weichand et al. also revealed that TAMs signal through the S1PR1/NLRP3/IL-1 $\beta$ cascade to infiltrate into tumors to promote pulmonary metastasis and lymphatic angiogenesis in mouse breast cancer model. Increased NLRP3 expression in TAMs is correlated with lymph node invasion and metastasis in breast cancer patients [50].

\subsection{Promoting Metastasis}

Extensive evidence has shown a correlation between TAM recruitment and increased tumor cell invasiveness [51]. TAMs not only contribute to early epithelial-mesenchymal transition (EMT) of tumor cells but also help prepare a distant site primed to support metastatic growth. One of the primary mechanisms TAMs facilitate tumor cell invasion and migration is by secreting MMPs, serine proteases and cathepsins which disrupt cell junctions and basal membrane [52]. Vasiljeva et al. reported that TAM-derived cathepsin B promotes invasion and lung metastasis in PyMT breast cancer model [53]. Additionally, other recent reports also found that TAM-derived macrophage inflammatory protein $1-\beta$ and TGF- $\beta$ can both lead to cancer cell matrix protrusion and invasion in breast cancer and non-small cell lung cancer, respectively [54,55]. TAMs also abundantly produce CCL18 which triggers integrin clustering around human breast cancer cells and allows for their adherence to ECM through interactions with the phosphatidylinositol transfer protein, membrane-associated 3 receptor (PITPNM3), resulting in enhanced intravasation, metastasis and reduced patient survival [56]. TAMs also produce several other molecules that augment cell invasion and metastasis. Lim et al. reported that increased S100A8 and S100A9 secretion from TAMs result in tumor invasion and migration in colon and Lewis lung carcinoma cells [57]. TAM-derived Secreted Protein Acidic and Rich in Cysteine (SPARC) enhances tumor extracellular matrix deposition and interaction [58].

In terms of enhancing EMT, using two solid tumor models, researchers showed that macrophage-derived TGF- $\beta$ induced EMT-mediating pathway in tumor cells, resulting in increased expression of mesenchymal markers and an invasive phenotype [59-61]. Lastly, the identification of a distinct population of VEGFR $1^{\text {high }}$ CX $3 C R 1^{\text {high }}$ CCR $2^{\text {high }}$ but Tie2 ${ }^{-}$ macrophage at the lung metastatic site in a spontaneous breast cancer model demonstrated that macrophages not only serve to prepare the pre-metastatic niche to increase metastatic efficiency but also foster cancer cell survival and growth at the distant site [62].

\subsection{Suppressing Adaptive Immune Responses}

Substantial evidence has supported that pro-tumorigenic TAMs can subvert tumorinfiltrating T lymphocytes functions directly and further modify the immune cell composition within the TME to decrease antitumoral immune cells while simultaneously increase the presence of immunosuppressive cell types to accelerate tumorigenesis. TAMs contribute greatly to tumor immune evasion by exerting immunosuppression on adaptive immune 
responses through the secretion of cytokines, chemokines, and enzymes directly or indirectly $[63,64]$. They serve as crucial drivers of chronic tumor-associated inflammation, and work in concert with tumor cells and other stromal cells in the tumor microenvironment to promote tumor progression.

TAMs suppress $C D 8^{+} \mathrm{T}$ cell activation via several major mechanisms: (1) interference of CD8 T cell trafficking to the tumor site; (2) depletion of metabolites essential for $\mathrm{T}$ cell proliferation; (3) secretion of anti-inflammatory cytokines; and (4) activation of T cell checkpoint blockade. Peranzoni et al. showed that depletion of TAMs using a CSF-1 receptor inhibitor enhances CD8 $\mathrm{T}$ cell migration and infiltration into tumor islets [65]. Our laboratory further demonstrated that hedgehog signaling in hepatocellular carcinoma promotes the immunosuppressive M2 phenotype of TAMs, which further impedes CD8 ${ }^{+}$ cytotoxic T lymphocyte trafficking into the tumor stroma via suppression of CXCL9 and CXCL10 [24]. Additionally, metabolism of L-arginine and L-tryptophan, catalyzed by TAM-derived arginase- 1 and indoleamine dioxygenase $1 / 2$ (IDO 1/2), respectively, results in the failure to re-express CD3 $\zeta$-chain in the T cell receptor (TCR) complex and inability to respond to tumor antigen [66-68]. $\mathrm{CD}^{+} \mathrm{T}$ cells are also highly sensitive to the $\mathrm{L}$-arginine level as it is required for the development of memory $\mathrm{T}$ cells which confers longer lasting cancer immunity [69]. Another power regulator of $\mathrm{T}$ cell suppression is tissue hypoxia, which augments the levels of HIF- $1 \alpha$ and HIF- $2 \alpha$ in TAMs. Higher levels of HIF- $1 \alpha$ and HIF- $2 \alpha$ can subsequently upregulate Arg1 and iNOS levels to exhaust L-arginine and increase NO in the TME [70]. Furthermore, anti-inflammatory cytokines, including IL-10, TGF- $\beta$, prostaglandin-E2 $\left(\mathrm{PGE}_{2}\right)$ produced by TAMs can inhibit cytotoxic $\mathrm{CD} 8^{+}$and helper $\mathrm{CD}^{+}$cells to establish an overwhelmingly immunosuppressive TME [63,71,72]. TAMs are the primary source of cytokine IL-10 within the tumor microenvironment such as in mammary carcinomas, and can indirectly blunt $\mathrm{CD} 8^{+} \mathrm{T}$ cell responses by inhibiting $\mathrm{DC}$ production of IL-12 or directly on $\mathrm{CD}^{+}{ }^{+} \mathrm{T}$ cells, inhibiting proliferation and production of IL-2, IFN- $\gamma$, and TNF- $\alpha$, resulting in suppressing proinflammatory responses within the tumor microenvironment [63]. TAMs also express TGF- $\beta$, a cytokine with multiple immunosuppressive properties in various tumor models. These properties include inhibition of T-cell proliferation, inhibition of T-cell differentiation into cytotoxic $\mathrm{T}$ lymphocytes (CTLs) and helper T cells, and inhibition of the T-cell stimulatory functions of APCs [73]. IL-10 and TGF- $\beta$ have been implicated in promoting T cell exhaustion, characterized by the loss of effector functions and the inability to transition into memory $\mathrm{T}$ cells, both in models of chronic viral infections and cancer [74]. Lastly, TAMs can suppress the function of tumor-infiltrating lymphocytes (TILs) by expressing the ligands of the inhibitory receptors PD-1 and CTLA-4 [75,76]. When activated by ligands, PD-L1, PD-L2 and B7-1 (CD80), B7-2 (CD86), PD-1, and CTLA-4, respectively, inhibit downstream TCR and BCR signaling, T cell activation, proliferation, and cytotoxic functions. Our laboratory found that tumor-derived Shh ligand promotes PD-L1 expression on TAMs in a mouse hepatocellular carcinoma model and higher expression of PD-L1 results in suppressed production of IFN- $\gamma$ and granzyme-B in CD8+ TILs [27]. Another challenge previously encountered was to decipher the relative contribution of TAM-expressed PD-L1 on T cell suppression in the TME as tumor cells and various other cell types also express PD-L1 [77]. Our recent study provided definitive evidence that TAM-expressed PD-L1 plays a major role in suppressing TILs using a CD274/PD-L1 conditional knockout mouse model [27].

In addition to suppressing anti-tumorigenic effector cells, TAMs also help attract or induce immunosuppressive cells at the tumor site. $\mathrm{T}_{\text {reg }}$ cells, a subset of $\mathrm{CD} 4^{+} \mathrm{T}$ cells characterized by its ability to dampen immune responses, are attracted to the tumor stroma via chemokine receptors CCR4, CCR5, CCR6, and CCR10 [78]. TAMs in ovarian and colorectal cancers produce CCL17/CCL22 and CCL20, which act on CCR4 ${ }^{+}$and CCR6 ${ }^{+}$ $\mathrm{T}_{\text {reg, }}$, respectively, to induce $\mathrm{T}_{\text {reg }}$ migration to the TME. In these cases, the accumulation of $\mathrm{T}_{\text {reg }}$ is associated with reduced patient survival $[79,80]$. In addition to recruitment of natural $\mathrm{T}_{\text {reg }}$ to the tumor stroma, TAMs are also involved in the induction of $\mathrm{T}_{\text {reg }}$ cells in the TME through regulation of Foxp3 via IL-10 and TGF- $\beta$ signaling [81,82]. However, circulating 
levels of $\mathrm{T}_{\text {reg }}$ and TGF- $\beta$ have been found to be associated with clinical benefit from immune checkpoint inhibitors, pointing to the importance in discerning blood findings from those within the TME [83]. Lastly, TAMs found in human renal cell carcinoma tumor can induce CTLA-4 and Foxp3 expression in T lymphocytes in vivo, further emphasizing the critical role of TAMs in cancer-related inflammation, immunosuppression, and malignant progression [84].

Combined with secretion of inhibitory cytokines, chemokines and depleting essential nutrient required for CD8 $\mathrm{T}$ cell activation, TAMs achieve subversion of host immune response via interference of CD8 $\mathrm{T}$ cell trafficking to the tumor site, and activation of $\mathrm{T}$ cell checkpoint blockade by upregulating inhibitory ligands such as PD-L1. Targeting TAMs specifically in the tumor microenvironment to lift the suppressive forces on immune cells particularly $\mathrm{CD} 8^{+} \mathrm{T}$ cells and reinvigorate effector $\mathrm{T}$ cells may be an effective way to treat cancer.

\section{TAM-Targeting Immunotherapies}

TAM is an attractive target for cancer immunotherapy characterized by its heavy presence in the tumor stroma across a panel of human malignancies and unique ability to modulate a variety of immune cell functions and non-immune processes in cancer. To overcome the immunosuppressive and pro-tumorigenic functions of TAMs, current therapeutic strategies have focused on four major aspects-(1) limiting monocyte recruitment to the tumor site; (2) depleting TAMs; (3) reprogramming TAMs; and (4) targeting inhibitory molecules on TAMs (Figure 2). Several reviews have highlighted pre-clinical studies and clinical trials that target TAMs in cancer [85-88]. We will focus on some of the recent successes below and summarize agents studied in clinical trials in Table 1.

Table 1. Summary of TAM-targeting Therapies in Clinical Trials.

\begin{tabular}{|c|c|c|c|c|}
\hline Treatment Strategy & Agent Name & Mechanism & Phase & $\begin{array}{c}\text { Clinical Trial } \\
\text { Number/Reference * }\end{array}$ \\
\hline \multirow[t]{7}{*}{ Limiting monocyte recruitment } & PF-04136309 & CCR2 antagonist & $1 b$ & NCT01413022 [89] \\
\hline & CCX872 & CCR2 antagonist & $1 b$ & NCT02345408 [90] \\
\hline & Carlumab & CCL2 antibody & $\mathrm{Ib}$ & NCT01204996 [91] \\
\hline & & & I & NCT00537368 [92] \\
\hline & & & II & NCT00992186 [93] \\
\hline & LY2510924 & CXCR4 antibody & $\mathrm{I}$ & NCT02737072 [94] \\
\hline & Motixafortide & CXCR4 antagonist & $\mathrm{IIb}$ & NCT02907099 [95] \\
\hline \multirow[t]{6}{*}{ Depleting TAMs } & PLX3397 & CSF-1R antibody & III & NCT02371369 [96] \\
\hline & & & $\mathrm{Ib}$ & NCT01525602 [97] \\
\hline & RG7155 & CSF-1R antibody & I & NCT01494688 [98] \\
\hline & AMG 820 & CSF-1R antibody & I & NCT01444404 [99] \\
\hline & IMC-CS4 & CSF-1R antibody & I & NCT01346358 [100] \\
\hline & MCS110 & CSF-1 antibody & $\mathrm{Ib} / \mathrm{II}$ & NCT02807844 [101] \\
\hline \multirow[t]{8}{*}{ Reprogramming TAMs } & Imiquimod & TLR7 agonist & II & NCT00899574 [102] \\
\hline & Motolimod & TLR8 agonist & II & NCT01836029 [103] \\
\hline & APX005M & CD40 agonist & $\mathrm{I} / \mathrm{II}$ & NCT03214250 [104] \\
\hline & RO7009789 & CD40 agonist & I & NCT02665416 \\
\hline & SEA-CD40 & CD40 agonist & I & NCT02376699 \\
\hline & CP-870893 & CD40 agonist & $\mathrm{I}$ & NCT01103635 \\
\hline & IPI-549 & $\mathrm{PI} 3 \mathrm{~K} \gamma$ inhibitor & $\mathrm{Ib}$ & NCT02637531 \\
\hline & & & II & NCT03961698 \\
\hline \multirow[t]{8}{*}{ Targeting inhibitory molecules on TAMs } & Hu5F9-G4 & CD47 antibody & I & NCT02216409 [105] \\
\hline & & & $\mathrm{I} / \mathrm{II}$ & NCT02953509 [106] \\
\hline & & & I & NCT03558139 \\
\hline & & & $\mathrm{I} / \mathrm{II}$ & NCT02953782 \\
\hline & CC90002 & CD47 antibody & I & NCT02367196 \\
\hline & TTI-621 & SIRP antibody & I & NCT02663518 \\
\hline & & & $\mathrm{I} / \mathrm{II}$ & NCT04996004 \\
\hline & CC-95251 & SIRP antibody & I & NCT03783403 \\
\hline
\end{tabular}

* Reference is included when trial has published results. 


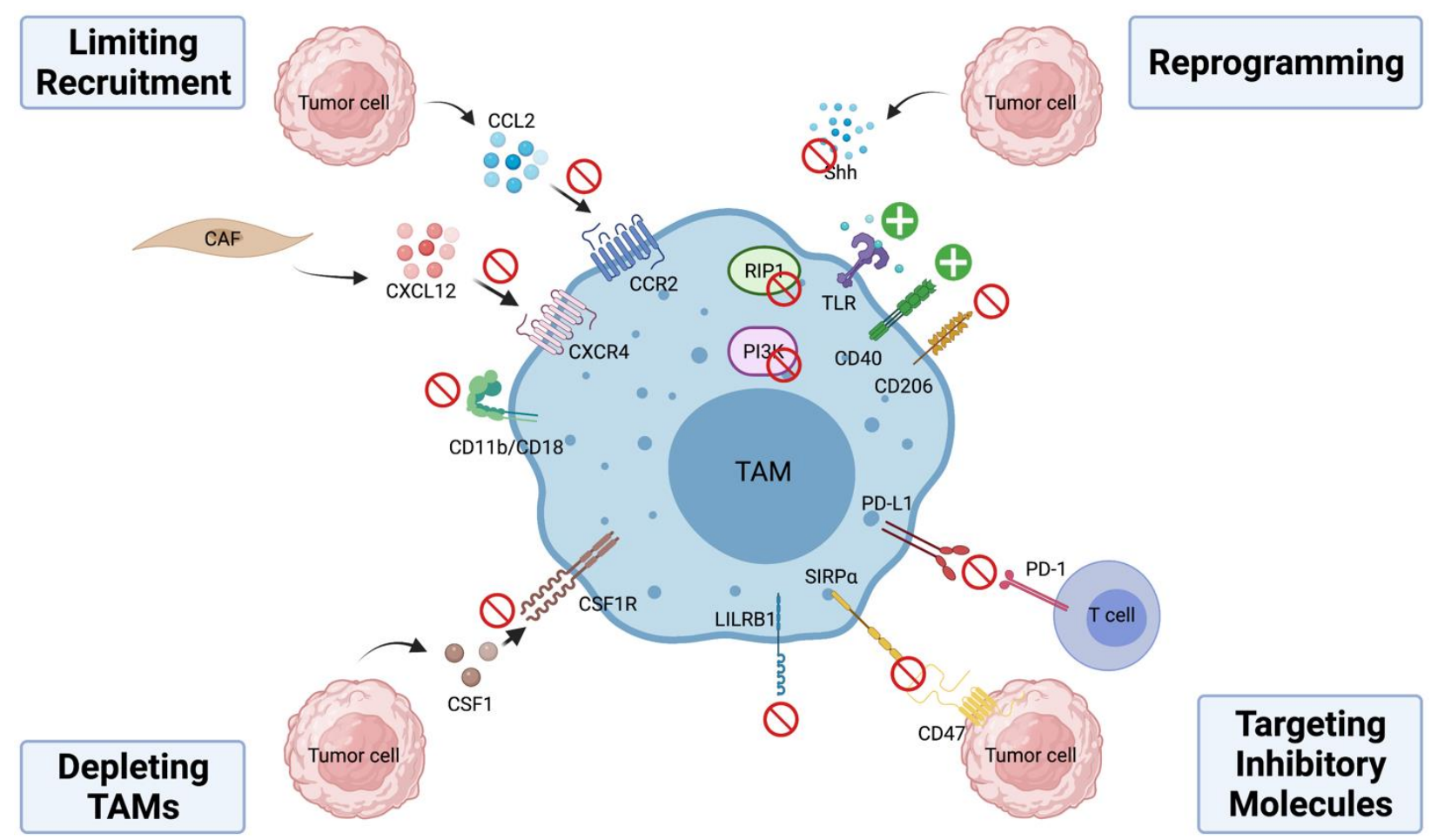

Figure 2. TAM-targeting immunotherapies. Current therapeutic strategies have focused on four major aspects-(1) limiting monocyte recruitment to the tumor site; (2) depleting TAMs; (3) reprogramming TAMs; and (4) targeting inhibitory molecules on TAMs. Inhibition is indicated by red circles while activation is marked by green plus signs. Abbreviations: CAF-cancerassociated fibroblast; CCL2-C-C motif chemokine ligand 2; CCR2-C-C motif chemokine receptor 2; CXCL12-C-X-C motif chemokine ligand 12; CXCR4-C-X-C motif chemokine receptor 4; CD11b/CD18 — macrophage-1 antigen; CSF1— colony stimulating factor 1; CSF1R—colony stimulating factor 1 receptor; Shh—sonic hedgehog; RIP1—receptor interacting protein 1; PI3K-phosphoinositide 3-kinase; TLR—Toll-like receptor; CD206-mannose receptor; PD-1-programmed cell death protein 1; PD-L1—programmed death ligand 1; CD47-integrin associated protein; SIRP $\alpha$-signal-regulatory protein alpha; LILRB1-leukocyte immunoglobulin like receptor B1. Created with BioRender.com.

\subsection{Limiting Monocyte Recruitment}

Trafficking of monocytes from bone marrow to the tumor site requires the CCL2-CCR2 signaling axis [22]. In various human neoplasia, higher levels of CCL2 are correlated with increased occurrence of metastasis and decreased overall survival $[107,108]$. In mouse models, inactivation of CCL2-CCR2 signaling achieved by gene knockout or inhibition of CCR2 by small molecule inhibitors reduced tumor growth and metastatic spread [109-111]. PF-04136309 is an investigational compound that prevents CCR2 activation and downstream signaling by interfering with CCL2-CCR2 interactions. In a Phase-1b clinical trial comparing a standard chemotherapy regimen FOLFIRINOX (oxaliplatin, irinotecan, leucovorin and fluorouracil) plus PF-04136309 to FOLFIRINOX alone in patients with locally advanced pancreatic ductal adenocarcinoma (PDAC), the addition of PF-04136309 resulted in a reduction in the infiltration of TAMs and $\mathrm{T}_{\text {reg }}$ and an increase in $\mathrm{CD} 4^{+}$and CD8 ${ }^{+}$ effector cells, which was correlated with improved treatment response in this group [89]. Recently, Linehan et al. reported that CCX872, a CCR2 specific antagonist showed better overall survival and lower peripheral blood monocyte counts when combined with FOLFIRINOX compared to FOLFIRINOX alone in locally advanced/metastatic PDAC patients [90]. In addition to PF-04136309 and CCX872, Carlumab (CNTO88), a human anti-CCL2 IgG1 $\mathrm{k}$ monoclonal antibody $(\mathrm{mAb})$ was evaluated in patients with solid tumors and showed some preliminary anti-tumor activity. However, its clinical efficacy is limited by only transient suppression of CCL2 [91-93]. 
Another chemokine, C-X-C motif chemokine ligand 12 (CXCL12) has also been shown to promote macrophage infiltration, accumulation, and survival in tumors [112,113]. In a recent study, Li et al. reported that cancer-associated fibroblast-derived CXCL12 attracts M2-polarized monocytes/macrophages and blocking of C-X-C motif chemokine receptor 4 (CXCR4), the receptor of CXCL12 results in significantly reduced infiltration of protumorigenic TAMs [114]. Mota et al. also observed increased TAM accumulation and tumor progression in a post-sepsis state associated with increased CXCL12/CXCR4 signaling in mice [115]. In a preclinical study using an ovarian cancer model, dual blockade of the CXCL12/CXCR4 and PD-1-PD-L1 signaling cascades effectively reduces tumor burden and prolongs survival in tumor-bearing mice [116]. Multiple clinical studies are currently investigating the effects of CXCR4 blockade in solid tumors with early results [94,95]. Lastly, integrin $\alpha \mathrm{M} \beta 2$ (CD11b/CD18) is an integrin expressed on myeloid cells that plays a critical role in leukocyte migration and tissue recruitment under inflammatory conditions [117]. Neutralizing monoclonal antibodies against CD11b were shown to reduce recruitment of myeloid cells into squamous cell carcinoma and attenuate tumor growth especially in combination with radiation [118]. Panni et al. utilized a novel strategy by using a partial activator of $\mathrm{CD} 11 \mathrm{~b}, \mathrm{ADH}-503$ that increases CD11-dependent cell adhesions on the endothelium to prevent subsequent tissue extravasation and found that ADH-503 effectively reduces the number of tumor-infiltrating myeloid cells in murine pancreatic cancer [119]. Collectively, these preclinical and clinical data suggest limiting TAM infiltration is an effective way to curb the immunosuppressive presence of TAMs in various solid tumors.

\subsection{Depleting TAMs}

CSF-1 is a critical regulator for the differentiation and survival of TAMs; inhibition of CSF1-CSF1R signaling can effectively reduce viability of TAMs [2]. In several preclinical studies, researchers have demonstrated CSF1-CSF1R signaling blockade slowed primary tumor growth, reduced metastatic potential, and improved long-term survival of tumorbearing mice [120-122]. BLZ945 is a potent and selective CSF-1R inhibitor which was shown to attenuate tumor growth by depleting TAMs and enriching $\mathrm{CD} 8^{+} \mathrm{T}$ cells in a murine K14-HPV-16 cervical cancer mouse model [122]. Another agent, PLX3397 selectively inhibits CSF-1R and two other tyrosine kinase receptors KIT and FLT3 [123]. Blockage of CSF-1R with PLX3397 not only improved the efficacy of adoptive cell therapy through inhibition of immunosuppressive macrophage recruitment and activation in murine melanoma but also potentiated the response of xenograft glioblastoma to ionizing radiation (IR) by preventing differentiation and pro-tumoral activation of IR-recruited monocytes in mice $[124,125]$. In a human phase III study evaluating efficacy of PLX3397 vs. placebo in tenosynovial giant-cell tumor, treatment with PLX3397 showed robust tumor response with improved patient symptoms and functional outcomes [96]. Furthermore, Wesolowski et al. reported that the combination of PLX3397 with paclitaxel showed promising results in advanced solid tumors [97]. Additionally, a neutralizing antibody Emactuzumab (RG7155) against CSF1R reduced macrophage infiltration in mouse models and demonstrated similar therapeutics effects against diffuse-type giant cell tumor in patients [98]. Other neutralizing antibodies against CSF1R-AMG 820 (NCT01444404), IMC-CS4 (NCT01346358), and MCS110 (NCT02807844) are also currently under Phase I/II clinical trials for their efficacy in treatment of advanced solid tumors as a monotherapy [99-101]. Many ongoing trials are also investigating the efficacy of CSF1/CSF1R inhibition in combination with traditional chemotherapies or novel immunotherapies in solid tumors as well as hematologic malignancies [126].

\subsection{Reprogramming TAMs}

Activation of Toll-like receptors (TLRs) expressed on macrophages leads to M1 polarization through NF- $\kappa$ B signaling. Due to this, TLR agonists have been evaluated in various mouse models for their ability to reprogram TAM functions to destroy tumor cells [127]. 
Local delivery of a TLR7/8 agonist 3M-052 boosted systemic antitumor immunity by repolarizing TAMs to a M1 NO-producing phenotype and resulted in eradication of murine metastatic melanoma. In addition, combining 3M-052 with antibodies against CTLA-4 and PD-L1 is synergistic in targeting established murine B16.F10 melanoma by rescuing TAM and cytotoxic $\mathrm{CD} 8^{+} \mathrm{T}$ cell tumoricidal functions [128]. Using topical TLR7 agonist imiquimod in patients with skin metastases from breast cancer showed $20 \%$ partial response with histologic tumor regression with changes in tumor lymphocytic infiltrate and local cytokines profile [102]. Motolimod, a TLR8 agonist in addition to standard combination chemotherapy and cetuximab was evaluated in a randomized multicenter clinical trial in patients with squamous cell carcinoma of the head and neck. Though the addition did not improve progression-free survival or overall survival, significant benefit was observed in HPV-positive patients, suggesting TLR8 therapy may benefit a subset of patients [103].

Aside from TLR activation, another strategy to activate pro-inflammatory TAMs includes the use of CD40 agonists. Upon activation, CD40, a member of the TNF receptor family that is highly expressed on antigen-presenting cells such as macrophages, drives pro-inflammatory cytokine release and expression of CD80/CD86 to support T cell functions [129-131]. Stromnes and colleagues also provided direct evidence that induction of CD40 on TAMs significantly increased the number of proliferating and GramzymeB+ $\mathrm{T}$ cells and decreased tumor cell survival in mice [132]. Using a PDAC mouse model, Beatty et al. showed that CD40-activated macrophages rapidly infiltrated tumors and are tumoricidal [133]. Additionally, combining anti-CD $40 \mathrm{mAb}$ with CSF-1R inhibitors potently suppressed tumor growth in an autochthonous poorly immunogenic mouse melanoma model. This was correlated with decreased production of MMP9 and CCL17/22 and increased expression of TNF- $\alpha$, IL-6 and IL-12 in TAMs [134]. Lastly, Diggs et al. found that CD40 agonism sensitizes previously resistant murine intrahepatic cholangiocarcinoma to PD-1 therapy and such effects are mediated through intratumoral macrophages and dendritic cells [135]. The clinical applicability of CD40 agonism was shown in human metastatic pancreatic adenocarcinoma where O'Hara et al. found that APX005M, a CD40 agonistic $\mathrm{mAb}$ combined with chemotherapy, with or without nivolumab shows potentially beneficial clinical activity [104]. Several other CD40 agonists-RO7009789 (NCT02665416), SEA-CD40 (NCT02376699), and CP-870893 (NCT01103635) are currently undergoing phase I clinical trials.

Other exciting advances in efforts to reprogram TAMs in the recent years aim at shifting M2-polarized TAMs into a more phagocytic and pro-inflammatory M1 phenotype. Selective repolarization of TAMs is a promising immunotherapeutic strategy as it would avoid serious side effects such as systemic inflammation, which is harmful to patients, and also disrupt subsequent TAM-derived metabolites that work to foster tumor growth. Wang and colleagues found that using a twin-like core-shell nanoparticles to deliver a TAM repolarization agent IMD-0354 has synergistic antitumor efficacy when combined with traditional sorafenib in mouse models [136]. RP-182, a synthetic molecule that can selectively induce conformational change of the mannose receptor CD206 expressed on TAMs, programs TAMs to an antitumor M1-like phenotype. This results in suppressed tumor growth and extended survival in murine cancer models [137]. Wang et al. reported that inhibition of receptor-interacting serine/threonine protein kinase 1 (RIP1) in TAMs shifted TAMs toward an MHCII ${ }^{\text {hi }} \mathrm{TNF} \alpha^{+}$IFN $\gamma^{+}$immunogenic phenotype in a Stat1-dependent mechanism [138]. Additionally, several animal models including PDAC have shown that suppression of PI3K $\gamma$ signaling reprograms TAMs to reinstate immune surveillance and hamper tumor progression $[139,140]$. We also recently demonstrated that inhibition of hedgehog signaling in TAMs increased M1-associated cytokine and chemokine productions while suppressing M2 polarization in mouse hepatoma and Lewis lung carcinoma [24]. This suggests that Shh, which is commonly upregulated in various human cancers, can be an attractive target in cancer immunotherapy for its effects on TAMs in addition to cancer cells. Lastly, others have investigated the possibility of using reprogrammed TAMs as "Trojan Horses" to deliver drugs directly to the tumor site, which aims to promote immune- 
mediated destruction by inducing tumor microenvironmental changes within the tumor while avoiding the systemic inflammation and toxicity often associated with large scale, indiscriminate administration of treatments [141,142]. This raises exciting possibilities for future novel TAM-targeted therapeutic development. Overall, these data demonstrate reprogramming/repolarizing TAMs is a promising strategy in promoting the tumoricidal effects while minimizing their immunosuppressive functions.

\subsection{Targeting Inhibitory Molecules on TAMs}

Like the role of immune checkpoint receptors PD-1 and CTLA-4 play in suppressing effector T cell functions, the CD47-SIRP $\alpha$ signaling axis inhibits the antibody-dependent phagocytosis of tumor cells by macrophages. CD47, which is highly expressed on the cancer cell surface, engages SIRP $\alpha$ on TAMs to transmit the "no kill" signal. Several CD47SIRP $\alpha$ antagonists are currently active in clinical trials, including Hu5F9-G4, CC90002, TTI-621 and ALX-148. Hu5F9-G4 and CC90002 are humanized monoclonal antibodies against CD47 while TTI-621 and ALX-148 are SIRP $\alpha$-IgGFC fusion proteins that can act as decoy receptors [143]. In small cell lung cancer (SCLC), Weiskopf et al. showed that Hu5F9-G2 induced macrophage-mediated phagocytosis of human SCLC cells in vitro. Additionally, in vivo administration of Hu5F9-G4 resulted in suppressed SCLC tumor growth in mice [144]. Another group of researchers demonstrated that Hu5F9-G4 has therapeutic efficacy in vitro and in vivo in patient-derived orthotopic xenograft models of five aggressive pediatric brain tumors [145]. Recently, Upton et al. showed that Hu5F9-G4 combined with trastuzumab can overcome trastuzumab tolerance in HER2+ breast cancer by enhancing antibody-dependent cellular phagocytosis [146]. Petrova et al. also showed that TTI-621 promoted macrophage-mediated tumor killing in a wide array of solid and hematologic malignancies [147]. In clinical trials, Sikic et al. showed that Hu5F9-G4 is well tolerated in patients with advanced solid tumors and Advani et al. demonstrated Hu5F9G4's promising antitumor activity in non-Hodgkin's lymphoma [105,106]. Other clinical trials are currently underway to investigate other antagonists of the CD47-SIRP $\alpha$ pathway.

Another inhibitory molecule expressed by macrophage is leukocyte immunoglobulinlike receptor subfamily B (LILRB). It was found that LILRB1 is upregulated on the surface of TAMs, and its ligand $\beta 2$-microglobulin expressed by tumor cells can protect LILRB1 from being engulfed. Disruption of this interaction enhances phagocytosis of tumor cells both in vitro and in vivo, suggesting this signal axis is an important regulator of effector functions of TAMs and a potential therapeutic target [148].

It has been reported that many types of human cancers have upregulated PD-L1 expression. In addition, PD-L1 is also commonly expressed on TAMs [149-151]. However, the source for PD-L1 in the tumor microenvironment is likely tumor-type specific and varies with different stages of tumor development. Using single cell RNA sequencing data, our laboratory recently showed that PD-L1 expression is mainly found in the myeloid population rather than tumor cells in human hepatocellular carcinoma and intraductal cholangiocarcinoma samples and that the expression of PD-L1 on TAMs is highly dependent on intact hedgehog signaling cascade in these macrophages [27]. Therefore, targeting TAMs and its interactions with cytotoxic T cells by combining hedgehog pathway inhibitor such as vismodegib and PD-1 antibody showed highly synergistic anti-tumor effects in mouse models of hepatoma and Lewis lung carcinoma [24]. This demonstrates the importance of targeting immunoinhibitory molecules on TAMs and the need to explore therapeutic approaches that combine multiple TAM-targeting strategies.

\section{Conclusions and Future Directions}

TAMs are key players in cancer progression via promotion of tumor proliferation, angiogenesis, metastasis, and immune evasion. Disrupting the mutually beneficial, positive feedback loop interactions between TAMs and cancer cells has significant implications in breaking the vicious cycle of progressive immunosuppression in the tumor microenvironment. In this review, we highlighted several mechanisms to target the pro-tumorigenic and 
immunosuppressive functions of TAMs, including reducing TAM recruitment, depleting or reprogramming TAMs and targeting immunomodulatory molecules on TAMs.

Though promising, the underlying mechanisms of many TAM-targeting therapeutics remain elusive. There is a need for more comprehensive understanding of the induction and functions of TAMs within the tumor microenvironment. Specifically, more investigation is needed for the mechanisms that attract TAMs into the tumor microenvironment and molecules that promote their immunosuppressive phenotype. Current therapies are reliant on targeting several key cascades, such as the CCL2-CCR2, CXCL12-CXCR4, and the CSF1-CSF1R pathways. However, emerging evidence has suggested that the functions of these pathways can be highly context- and tumor subtype-dependent, which may explain the highly variable anti-tumoral effects of these monotherapies. Additionally, as the tumor stroma is a remarkably complex and dynamic environment, further elucidation of novel pathways that may contribute to TAM polarization and immunosuppression is greatly needed. Lastly, our previous reports have highlighted the intimate interactions between TAMs and cytotoxic T cells-not only can TAMs interfere with $\mathrm{CD} 8^{+} \mathrm{T}$ cell trafficking, but they can also directly interact with immune checkpoint inhibitors such as via the PD-L1-PD-1 pathway resulting in T cell exhaustion. Therefore, delineating the mechanisms underlying the upregulation of PD-L1 by TAMs, and defining the role of TAM-derived PD-L1 in CD8 T cell dysfunction within the tumor microenvironment will offer important insights into tumor-TAM-anti-tumor $\mathrm{T}$ cell interactions within the tumor microenvironment, and help guide strategies to modulate TAM functions from immunosuppressive to immunostimulating, and reinvigorate cytotoxic $\mathrm{T}$ cells and other effector cells. As many therapies that target TAMs are currently being investigated as monotherapies or in addition to traditional chemotherapies, there is a great need to study the potential synergistic effects of TAM-targeting therapies with other effector cells-enhancing strategies to finally overcome the overwhelmingly immunosuppressive tumor microenvironment.

Author Contributions: Conceptualization, A.J.P., Y.Y. and X.H..; methodology, A.J.P., Y.Y. and X.H.; resources, D.H.O., Y.Y. and X.H.; writing—original draft preparation, A.J.P. and X.H.; writing-review and editing, A.J.P., D.H.O., Y.Y. and X.H.; visualization, A.J.P. and X.H.; supervision, Y.Y. and X.H.; project administration, Y.Y. and X.H.; funding acquisition, A.J.P., Y.Y. and X.H. All authors have read and agreed to the published version of the manuscript.

Funding: This work was supported by NIH grants CA136934, CA186973, and CA193167. AJP was supported by NIH predoctoral fellowship CA213799.

Conflicts of Interest: The authors declare no conflict of interest. DHO reports research funding to institution outside the scope of this work from Genentech, BMS, Merck, Palobiofarma, Pfizer.

\section{References}

1. Biswas, S.K.; Mantovani, A. Macrophage plasticity and interaction with lymphocyte subsets: Cancer as a paradigm. Nat. Immunol. 2010, 11, 889-896. [CrossRef] [PubMed]

2. Qian, B.Z.; Pollard, J.W. Macrophage diversity enhances tumor progression and metastasis. Cell Added 2010, 141, 39-51. [CrossRef]

3. Sica, A.; Mantovani, A. Macrophage plasticity and polarization: In vivo veritas. J. Clin. Investig. 2012, 122, 787-795. [CrossRef]

4. Xue, J.; Schmidt, S.V.; Sander, J.; Draffehn, A.; Krebs, W.; Quester, I.; De Nardo, D.; Gohel, T.D.; Emde, M.; Schmidleithner, L.; et al. Transcriptome-based network analysis reveals a spectrum model of human macrophage activation. Immunity 2014, 40, 274-288. [CrossRef]

5. Mantovani, A.; Biswas, S.K.; Galdiero, M.R.; Sica, A.; Locati, M. Macrophage plasticity and polarization in tissue repair and remodelling. J. Pathol. 2013, 229, 176-185. [CrossRef]

6. Krzyszczyk, P.; Schloss, R.; Palmer, A.; Berthiaume, F. The Role of Macrophages in Acute and Chronic Wound Healing and Interventions to Promote Pro-wound Healing Phenotypes. Front. Physiol. 2018, 9, 419. [CrossRef]

7. Chen, M.; Forrester, J.V.; Xu, H. Dysregulation in retinal para-inflammation and age-related retinal degeneration in CCL2 or CCR2 deficient mice. PLOS ONE 2011, 6, e22818. [CrossRef]

8. Wang, Q.; Ren, J.; Morgan, S.; Liu, Z.; Dou, C.; Liu, B. Monocyte chemoattractant protein-1 (MCP-1) regulates macrophage cytotoxicity in abdominal aortic aneurysm. PLoS ONE 2014, 9, e92053. [CrossRef] [PubMed]

9. Gu, W.; Yao, L.; Li, L.; Zhang, J.; Place, A.T.; Minshall, R.D.; Liu, G. ICAM-1 regulates macrophage polarization by suppressing MCP-1 expression via miR-124 upregulation. Oncotarget 2017, 8, 111882-111901. [CrossRef] [PubMed] 
10. Gschwandtner, M.; Derler, R.; Midwood, K.S. More Than Just Attractive: How CCL2 Influences Myeloid Cell Behavior Beyond Chemotaxis. Front. Immunol. 2019, 10, 2759. [CrossRef]

11. Biswas, S.K.; Gangi, L.; Paul, S.; Schioppa, T.; Saccani, A.; Sironi, M.; Bottazzi, B.; Doni, A.; Vincenzo, B.; Pasqualini, F.; et al. A distinct and unique transcriptional program expressed by tumor-associated macrophages (defective NF-kappaB and enhanced IRF-3/STAT1 activation). Blood 2006, 107, 2112-2122. [CrossRef] [PubMed]

12. Liu, Y.; Cao, X. The origin and function of tumor-associated macrophages. Cell. Mol. Immunol. 2015, 12, 1-4. [CrossRef]

13. Williams, C.B.; Yeh, E.S.; Soloff, A.C. Tumor-associated macrophages: Unwitting accomplices in breast cancer malignancy. NPJ Breast Cancer 2016, 2. [CrossRef]

14. Franklin, R.A.; Li, M.O. Ontogeny of Tumor-associated Macrophages and Its Implication in Cancer Regulation. Trends Cancer 2016, 2, 20-34. [CrossRef]

15. Movahedi, K.; Laoui, D.; Gysemans, C.; Baeten, M.; Stange, G.; Van den Bossche, J.; Mack, M.; Pipeleers, D.; In't Veld, P.; De Baetselier, P.; et al. Different tumor microenvironments contain functionally distinct subsets of macrophages derived from Ly6C(high) monocytes. Cancer Res. 2010, 70, 5728-5739. [CrossRef]

16. Franklin, R.A.; Liao, W.; Sarkar, A.; Kim, M.V.; Bivona, M.R.; Liu, K.; Pamer, E.G.; Li, M.O. The cellular and molecular origin of tumor-associated macrophages. Science 2014, 344, 921-925. [CrossRef]

17. Shand, F.H.; Ueha, S.; Otsuji, M.; Koid, S.S.; Shichino, S.; Tsukui, T.; Kosugi-Kanaya, M.; Abe, J.; Tomura, M.; Ziogas, J.; et al. Tracking of intertissue migration reveals the origins of tumor-infiltrating monocytes. Proc. Natl. Acad. Sci. USA 2014, 111, 7771-7776. [CrossRef]

18. Casanova-Acebes, M.; Dalla, E.; Leader, A.M.; LeBerichel, J.; Nikolic, J.; Morales, B.M.; Brown, M.; Chang, C.; Troncoso, L.; Chen, S.T.; et al. Tissue-resident macrophages provide a pro-tumorigenic niche to early NSCLC cells. Nature 2021, 595, 578-584. [CrossRef]

19. Zhu, Y.; Herndon, J.M.; Sojka, D.K.; Kim, K.W.; Knolhoff, B.L.; Zuo, C.; Cullinan, D.R.; Luo, J.; Bearden, A.R.; Lavine, K.J.; et al. Tissue-Resident Macrophages in Pancreatic Ductal Adenocarcinoma Originate from Embryonic Hematopoiesis and Promote Tumor Progression. Immunity 2017, 47, 323-338.e326. [CrossRef] [PubMed]

20. Quail, D.F.; Joyce, J.A. Microenvironmental regulation of tumor progression and metastasis. Nat. Med. 2013, 19, 1423-1437. [CrossRef] [PubMed]

21. Linde, N.; Lederle, W.; Depner, S.; van Rooijen, N.; Gutschalk, C.M.; Mueller, M.M. Vascular endothelial growth factor-induced skin carcinogenesis depends on recruitment and alternative activation of macrophages. J. Pathol. 2012, 227, 17-28. [CrossRef]

22. Qian, B.Z.; Li, J.; Zhang, H.; Kitamura, T.; Zhang, J.; Campion, L.R.; Kaiser, E.A.; Snyder, L.A.; Pollard, J.W. CCL2 recruits inflammatory monocytes to facilitate breast-tumour metastasis. Nature 2011, 475, 222-225. [CrossRef] [PubMed]

23. Noy, R.; Pollard, J.W. Tumor-associated macrophages: From mechanisms to therapy. Immunity 2014, 41, 49-61. [CrossRef]

24. Petty, A.J.; Li, A.; Wang, X.; Dai, R.; Heyman, B.; Hsu, D.; Huang, X.; Yang, Y. Hedgehog signaling promotes tumor-associated macrophage polarization to suppress intratumoral CD8+ T cell recruitment. J. Clin. Investig. 2019, 129, 5151-5162. [CrossRef] [PubMed]

25. Lawrence, T.; Natoli, G. Transcriptional regulation of macrophage polarization: Enabling diversity with identity. Nat. Rev. Immunol. 2011, 11, 750-761. [CrossRef]

26. Colegio, O.R.; Chu, N.Q.; Szabo, A.L.; Chu, T.; Rhebergen, A.M.; Jairam, V.; Cyrus, N.; Brokowski, C.E.; Eisenbarth, S.C.; Phillips, G.M.; et al. Functional polarization of tumour-associated macrophages by tumour-derived lactic acid. Nature 2014, 513, 559-563. [CrossRef]

27. Petty, A.J.; Dai, R.; Lapalombella, R.; Baiocchi, R.A.; Benson, D.M.; Li, Z.; Huang, X.; Yang, Y. Hedgehog-induced PD-L1 on tumor-associated macrophages is critical for suppression of tumor-infiltrating CD8+ T cell function. JCI Insight 2021, 6. [CrossRef]

28. Petty, A.J.; Yang, Y. Tumor-associated macrophages: Implications in cancer immunotherapy. Immunotherapy 2017, 9, 289-302. [CrossRef]

29. Petty, A.J.; Yang, Y. Tumor-Associated Macrophages in Hematologic Malignancies: New Insights and Targeted Therapies. Cells 2019, 8, 1526. [CrossRef] [PubMed]

30. Pan, Y.; Yu, Y.; Wang, X.; Zhang, T. Tumor-Associated Macrophages in Tumor Immunity. Front. Immunol. 2020, $11,583084$. [CrossRef]

31. Tong, H.; Ke, J.Q.; Jiang, F.Z.; Wang, X.J.; Wang, F.Y.; Li, Y.R.; Lu, W.; Wan, X.P. Tumor-associated macrophage-derived CXCL8 could induce ER $\alpha$ suppression via HOXB13 in endometrial cancer. Cancer Lett. 2016, 376, 127-136. [CrossRef] [PubMed]

32. Arima, K.; Komohara, Y.; Bu, L.; Tsukamoto, M.; Itoyama, R.; Miyake, K.; Uchihara, T.; Ogata, Y.; Nakagawa, S.; Okabe, H.; et al. Downregulation of 15-hydroxyprostaglandin dehydrogenase by interleukin-1 $\beta$ from activated macrophages leads to poor prognosis in pancreatic cancer. Cancer Sci. 2018, 109, 462-470. [CrossRef] [PubMed]

33. Kreso, A.; Dick, J.E. Evolution of the cancer stem cell model. Cell. Stem. Cell. 2014, 14, 275-291. [CrossRef]

34. Korkaya, H.; Liu, S.; Wicha, M.S. Regulation of cancer stem cells by cytokine networks: Attacking cancer's inflammatory roots. Clin. Cancer Res. 2011, 17, 6125-6129. [CrossRef]

35. Schwitalla, S.; Fingerle, A.A.; Cammareri, P.; Nebelsiek, T.; Goktuna, S.I.; Ziegler, P.K.; Canli, O.; Heijmans, J.; Huels, D.J.; Moreaux, G.; et al. Intestinal tumorigenesis initiated by dedifferentiation and acquisition of stem-cell-like properties. Cell 2013, 152, 25-38. [CrossRef] [PubMed] 
36. Wan, S.; Zhao, E.; Kryczek, I.; Vatan, L.; Sadovskaya, A.; Ludema, G.; Simeone, D.M.; Zou, W.; Welling, T.H. Tumor-associated macrophages produce interleukin 6 and signal via STAT3 to promote expansion of human hepatocellular carcinoma stem cells. Gastroenterology 2014, 147, 1393-1404. [CrossRef]

37. Yang, Z.; Xie, H.; He, D.; Li, L. Infiltrating macrophages increase RCC epithelial mesenchymal transition (EMT) and stem cell-like populations via AKT and mTOR signaling. Oncotarget 2016, 7, 44478-44491. [CrossRef]

38. Lu, H.; Clauser, K.R.; Tam, W.L.; Frose, J.; Ye, X.; Eaton, E.N.; Reinhardt, F.; Donnenberg, V.S.; Bhargava, R.; Carr, S.A.; et al. A breast cancer stem cell niche supported by juxtacrine signalling from monocytes and macrophages. Nat. Cell Biol. 2014, 16, 1105-1117. [CrossRef]

39. Jinushi, M.; Chiba, S.; Yoshiyama, H.; Masutomi, K.; Kinoshita, I.; Dosaka-Akita, H.; Yagita, H.; Takaoka, A.; Tahara, H. Tumorassociated macrophages regulate tumorigenicity and anticancer drug responses of cancer stem/initiating cells. Proc. Natl. Acad. Sci. USA 2011, 108, 12425-12430. [CrossRef]

40. Yang, J.; Liao, D.; Chen, C.; Liu, Y.; Chuang, T.H.; Xiang, R.; Markowitz, D.; Reisfeld, R.A.; Luo, Y. Tumor-associated macrophages regulate murine breast cancer stem cells through a novel paracrine EGFR/Stat3/Sox-2 signaling pathway. Stem Cells 2013, 31, 248-258. [CrossRef]

41. Mitchem, J.B.; Brennan, D.J.; Knolhoff, B.L.; Belt, B.A.; Zhu, Y.; Sanford, D.E.; Belaygorod, L.; Carpenter, D.; Collins, L.; PiwnicaWorms, D.; et al. Targeting tumor-infiltrating macrophages decreases tumor-initiating cells, relieves immunosuppression, and improves chemotherapeutic responses. Cancer Res. 2013, 73, 1128-1141. [CrossRef] [PubMed]

42. Kessenbrock, K.; Plaks, V.; Werb, Z. Matrix metalloproteinases: Regulators of the tumor microenvironment. Cell 2010, $141,52-67$. [CrossRef] [PubMed]

43. Murdoch, C.; Muthana, M.; Coffelt, S.B.; Lewis, C.E. The role of myeloid cells in the promotion of tumour angiogenesis. Nat. Rev. Cancer 2008, 8, 618-631. [CrossRef] [PubMed]

44. Valkovic, T.; Dobrila, F.; Melato, M.; Sasso, F.; Rizzardi, C.; Jonjic, N. Correlation between vascular endothelial growth factor, angiogenesis, and tumor-associated macrophages in invasive ductal breast carcinoma. Virchows Arch. 2002, 440, 583-588. [CrossRef]

45. Lin, E.Y.; Pollard, J.W. Tumor-associated macrophages press the angiogenic switch in breast cancer. Cancer Res. 2007, 67, 5064-5066. [CrossRef] [PubMed]

46. Forget, M.A.; Voorhees, J.L.; Cole, S.L.; Dakhlallah, D.; Patterson, I.L.; Gross, A.C.; Moldovan, L.; Mo, X.; Evans, R.; Marsh, C.B.; et al. Macrophage colony-stimulating factor augments Tie2-expressing monocyte differentiation, angiogenic function, and recruitment in a mouse model of breast cancer. PLoS ONE 2014, 9, e98623. [CrossRef] [PubMed]

47. Yeo, E.J.; Cassetta, L.; Qian, B.Z.; Lewkowich, I.; Li, J.F.; Stefater, J.A., 3rd; Smith, A.N.; Wiechmann, L.S.; Wang, Y.; Pollard, J.W.; et al. Myeloid WNT7b mediates the angiogenic switch and metastasis in breast cancer. Cancer Res. 2014, 74, 2962-2973. [CrossRef]

48. Mazzieri, R.; Pucci, F.; Moi, D.; Zonari, E.; Ranghetti, A.; Berti, A.; Politi, L.S.; Gentner, B.; Brown, J.L.; Naldini, L.; et al. Targeting the ANG2/TIE2 axis inhibits tumor growth and metastasis by impairing angiogenesis and disabling rebounds of proangiogenic myeloid cells. Cancer Cell 2011, 19, 512-526. [CrossRef]

49. Palazon, A.; Tyrakis, P.A.; Macias, D.; Veliça, P.; Rundqvist, H.; Fitzpatrick, S.; Vojnovic, N.; Phan, A.T.; Loman, N.; Hedenfalk, I.; et al. An HIF-1 $\alpha$ /VEGF-A Axis in Cytotoxic T Cells Regulates Tumor Progression. Cancer Cell 2017, 32, 669-683.e665. [CrossRef]

50. Weichand, B.; Popp, R.; Dziumbla, S.; Mora, J.; Strack, E.; Elwakeel, E.; Frank, A.C.; Scholich, K.; Pierre, S.; Syed, S.N.; et al. S1PR1 on tumor-associated macrophages promotes lymphangiogenesis and metastasis via NLRP3/IL-1ß. J. Exp. Med. 2017, 214, 2695-2713. [CrossRef]

51. Condeelis, J.; Pollard, J.W. Macrophages: Obligate partners for tumor cell migration, invasion, and metastasis. Cell 2006, 124, 263-266. [CrossRef]

52. Chanmee, T.; Ontong, P.; Konno, K.; Itano, N. Tumor-associated macrophages as major players in the tumor microenvironment. Cancers 2014, 6, 1670-1690. [CrossRef] [PubMed]

53. Vasiljeva, O.; Papazoglou, A.; Krüger, A.; Brodoefel, H.; Korovin, M.; Deussing, J.; Augustin, N.; Nielsen, B.S.; Almholt, K.; Bogyo, M.; et al. Tumor cell-derived and macrophage-derived cathepsin B promotes progression and lung metastasis of mammary cancer. Cancer Res. 2006, 66, 5242-5250. [CrossRef] [PubMed]

54. Baghel, K.S.; Tewari, B.N.; Shrivastava, R.; Malik, S.A.; Lone, M.U.; Jain, N.K.; Tripathi, C.; Kanchan, R.K.; Dixit, S.; Singh, K.; et al. Macrophages promote matrix protrusive and invasive function of breast cancer cells via MIP-1 $\beta$ dependent upregulation of MYO3A gene in breast cancer cells. Oncoimmunology 2016, 5, e1196299. [CrossRef] [PubMed]

55. Zhang, S.; Che, D.; Yang, F.; Chi, C.; Meng, H.; Shen, J.; Qi, L.; Liu, F.; Lv, L.; Li, Y.; et al. Tumor-associated macrophages promote tumor metastasis via the TGF- $\beta$ /SOX9 axis in non-small cell lung cancer. Oncotarget 2017, 8, 99801-99815. [CrossRef]

56. Chen, J.; Yao, Y.; Gong, C.; Yu, F.; Su, S.; Chen, J.; Liu, B.; Deng, H.; Wang, F.; Lin, L.; et al. CCL18 from tumor-associated macrophages promotes breast cancer metastasis via PITPNM3. Cancer Cell 2011, 19, 541-555. [CrossRef] [PubMed]

57. Lim, S.Y.; Yuzhalin, A.E.; Gordon-Weeks, A.N.; Muschel, R.J. Tumor-infiltrating monocytes/macrophages promote tumor invasion and migration by upregulating S100A8 and S100A9 expression in cancer cells. Oncogene 2016, 35, 5735-5745. [CrossRef]

58. Sangaletti, S.; Di Carlo, E.; Gariboldi, S.; Miotti, S.; Cappetti, B.; Parenza, M.; Rumio, C.; Brekken, R.A.; Chiodoni, C.; Colombo, M.P. Macrophage-derived SPARC bridges tumor cell-extracellular matrix interactions toward metastasis. Cancer Res. 2008, 68, 9050-9059. [CrossRef] 
59. Bonde, A.K.; Tischler, V.; Kumar, S.; Soltermann, A.; Schwendener, R.A. Intratumoral macrophages contribute to epithelialmesenchymal transition in solid tumors. BMC Cancer 2012, 12, 35. [CrossRef]

60. Cai, J.; Xia, L.; Li, J.; Ni, S.; Song, H.; Wu, X. Tumor-Associated Macrophages Derived TGF- $\beta$-Induced Epithelial to Mesenchymal Transition in Colorectal Cancer Cells through Smad2,3-4/Snail Signaling Pathway. Cancer Res. Treat. 2019, 51, 252-266. [CrossRef]

61. Fan, Q.M.; Jing, Y.Y.; Yu, G.F.; Kou, X.R.; Ye, F.; Gao, L.; Li, R.; Zhao, Q.D.; Yang, Y.; Lu, Z.H.; et al. Tumor-associated macrophages promote cancer stem cell-like properties via transforming growth factor-beta1-induced epithelial-mesenchymal transition in hepatocellular carcinoma. Cancer Lett. 2014, 352, 160-168. [CrossRef]

62. Qian, B.; Deng, Y.; Im, J.H.; Muschel, R.J.; Zou, Y.; Li, J.; Lang, R.A.; Pollard, J.W. A distinct macrophage population mediates metastatic breast cancer cell extravasation, establishment and growth. PLoS ONE 2009, 4, e6562. [CrossRef] [PubMed]

63. Ruffell, B.; Chang-Strachan, D.; Chan, V.; Rosenbusch, A.; Ho, C.M.; Pryer, N.; Daniel, D.; Hwang, E.S.; Rugo, H.S.; Coussens, L.M. Macrophage IL-10 blocks CD8+ T cell-dependent responses to chemotherapy by suppressing IL-12 expression in intratumoral dendritic cells. Cancer Cell 2014, 26, 623-637. [CrossRef] [PubMed]

64. Couper, K.N.; Blount, D.G.; Riley, E.M. IL-10: The master regulator of immunity to infection. J. Immunol. 2008, 180, 5771-5777. [CrossRef]

65. Peranzoni, E.; Lemoine, J.; Vimeux, L.; Feuillet, V.; Barrin, S.; Kantari-Mimoun, C.; Bercovici, N.; Guérin, M.; Biton, J.; Ouakrim, H.; et al. Macrophages impede CD8 T cells from reaching tumor cells and limit the efficacy of anti-PD-1 treatment. Proc. Natl. Acad. Sci. USA 2018, 115, E4041-e4050. [CrossRef]

66. Munn, D.H.; Sharma, M.D.; Baban, B.; Harding, H.P.; Zhang, Y.; Ron, D.; Mellor, A.L. GCN2 kinase in T cells mediates proliferative arrest and anergy induction in response to indoleamine 2,3-dioxygenase. Immunity 2005, 22, 633-642. [CrossRef]

67. Rodriguez, P.C.; Quiceno, D.G.; Ochoa, A.C. L-arginine availability regulates T-lymphocyte cell-cycle progression. Blood 2007, 109, 1568-1573. [CrossRef]

68. Rodriguez, P.C.; Zea, A.H.; DeSalvo, J.; Culotta, K.S.; Zabaleta, J.; Quiceno, D.G.; Ochoa, J.B.; Ochoa, A.C. L-arginine consumption by macrophages modulates the expression of CD3 zeta chain in T lymphocytes. J. Immunol. 2003, 171, 1232-1239. [CrossRef] [PubMed]

69. Mondanelli, G.; Iacono, A.; Allegrucci, M.; Puccetti, P.; Grohmann, U. Immunoregulatory Interplay Between Arginine and Tryptophan Metabolism in Health and Disease. Front. Immunol. 2019, 10, 1565. [CrossRef]

70. Noman, M.Z.; Janji, B.; Berchem, G.; Mami-Chouaib, F.; Chouaib, S. Hypoxia-induced autophagy: A new player in cancer immunotherapy? Autophagy 2012, 8, 704-706. [CrossRef]

71. Kalinski, P. Regulation of immune responses by prostaglandin E2. J. Immunol. 2012, 188, 21-28. [CrossRef]

72. Oh, S.A.; Li, M.O. TGF-beta: Guardian of T cell function. J. Immunol. 2013, 191, 3973-3979. [CrossRef] [PubMed]

73. Gorelik, L.; Flavell, R.A. Immune-mediated eradication of tumors through the blockade of transforming growth factor-beta signaling in T cells. Nat. Med. 2001, 7, 1118-1122. [CrossRef]

74. McLane, L.M.; Abdel-Hakeem, M.S.; Wherry, E.J. CD8 T Cell Exhaustion During Chronic Viral Infection and Cancer. Annu. Rev. Immunol. 2019, 37, 457-495. [CrossRef]

75. Kuang, D.M.; Zhao, Q.; Peng, C.; Xu, J.; Zhang, J.P.; Wu, C.; Zheng, L. Activated monocytes in peritumoral stroma of hepatocellular carcinoma foster immune privilege and disease progression through PD-L1. J. Exp. Med. 2009, 206, 1327-1337. [CrossRef] [PubMed]

76. Ojalvo, L.S.; King, W.; Cox, D.; Pollard, J.W. High-density gene expression analysis of tumor-associated macrophages from mouse mammary tumors. Am. J. Pathol. 2009, 174, 1048-1064. [CrossRef]

77. Greaves, P.; Gribben, J.G. The role of B7 family molecules in hematologic malignancy. Blood 2013, 121, 734-744. [CrossRef] [PubMed]

78. Adeegbe, D.O.; Nishikawa, H. Natural and induced T regulatory cells in cancer. Front. Immunol. 2013, 4, 190. [CrossRef]

79. Curiel, T.J.; Coukos, G.; Zou, L.; Alvarez, X.; Cheng, P.; Mottram, P.; Evdemon-Hogan, M.; Conejo-Garcia, J.R.; Zhang, L.; Burow, M.; et al. Specific recruitment of regulatory T cells in ovarian carcinoma fosters immune privilege and predicts reduced survival. Nat. Med. 2004, 10, 942-949. [CrossRef]

80. Liu, J.; Zhang, N.; Li, Q.; Zhang, W.; Ke, F.; Leng, Q.; Wang, H.; Chen, J.; Wang, H. Tumor-associated macrophages recruit CCR6+ regulatory $\mathrm{T}$ cells and promote the development of colorectal cancer via enhancing CCL20 production in mice. PLoS ONE 2011, 6, e19495. [CrossRef] [PubMed]

81. Denning, T.L.; Wang, Y.C.; Patel, S.R.; Williams, I.R.; Pulendran, B. Lamina propria macrophages and dendritic cells differentially induce regulatory and interleukin 17-producing T cell responses. Nat. Immunol. 2007, 8, 1086-1094. [CrossRef]

82. Savage, N.D.; de Boer, T.; Walburg, K.V.; Joosten, S.A.; van Meijgaarden, K.; Geluk, A.; Ottenhoff, T.H. Human anti-inflammatory macrophages induce Foxp3+ GITR+ CD25+ regulatory T cells, which suppress via membrane-bound TGFbeta-1. J. Immunol. 2008, 181, 2220-2226. [CrossRef]

83. Koh, J.; Hur, J.Y.; Lee, K.Y.; Kim, M.S.; Heo, J.Y.; Ku, B.M.; Sun, J.M.; Lee, S.H.; Ahn, J.S.; Park, K.; et al. Regulatory (FoxP3(+)) T cells and TGF- $\beta$ predict the response to anti-PD-1 immunotherapy in patients with non-small cell lung cancer. Sci. Rep. 2020, 10, 18994. [CrossRef]

84. Daurkin, I.; Eruslanov, E.; Stoffs, T.; Perrin, G.Q.; Algood, C.; Gilbert, S.M.; Rosser, C.J.; Su, L.M.; Vieweg, J.; Kusmartsev, S. Tumorassociated macrophages mediate immunosuppression in the renal cancer microenvironment by activating the 15-lipoxygenase-2 pathway. Cancer Res. 2011, 71, 6400-6409. [CrossRef] 
85. Anfray, C.; Ummarino, A.; Andón, F.T.; Allavena, P. Current Strategies to Target Tumor-Associated-Macrophages to Improve Anti-Tumor Immune Responses. Cells 2019, 9, 46. [CrossRef]

86. Tan, Y.; Wang, M.; Zhang, Y.; Ge, S.; Zhong, F.; Xia, G.; Sun, C. Tumor-Associated Macrophages: A Potential Target for Cancer Therapy. Front. Oncol. 2021, 11, 693517. [CrossRef]

87. Zhang, S.Y.; Song, X.Y.; Li, Y.; Ye, L.L.; Zhou, Q.; Yang, W.B. Tumor-associated macrophages: A promising target for a cancer immunotherapeutic strategy. Pharmacol. Res. 2020, 161, 105111. [CrossRef] [PubMed]

88. Mantovani, A.; Marchesi, F.; Malesci, A.; Laghi, L.; Allavena, P. Tumour-associated macrophages as treatment targets in oncology. Nat. Rev. Clin. Oncol. 2017, 14, 399-416. [CrossRef] [PubMed]

89. Nywening, T.M.; Wang-Gillam, A.; Sanford, D.E.; Belt, B.A.; Panni, R.Z.; Cusworth, B.M.; Toriola, A.T.; Nieman, R.K.; Worley, L.A.; Yano, M.; et al. Targeting tumour-associated macrophages with CCR2 inhibition in combination with FOLFIRINOX in patients with borderline resectable and locally advanced pancreatic cancer: A single-centre, open-label, dose-finding, non-randomised, phase $1 \mathrm{~b}$ trial. Lancet Oncol. 2016, 17, 651-662. [CrossRef]

90. Linehan, D.; Noel, M.S.; Hezel, A.F.; Wang-Gillam, A.; Eskens, F.; Sleijfer, S.; Desar, I.M.E.; Erdkamp, F.; Wilmink, J.; Diehl, J.; et al. Overall survival in a trial of orally administered CCR2 inhibitor CCX872 in locally advanced/metastatic pancreatic cancer: Correlation with blood monocyte counts. J. Clin. Oncol. 2018, 36, 92. [CrossRef]

91. Brana, I.; Calles, A.; LoRusso, P.M.; Yee, L.K.; Puchalski, T.A.; Seetharam, S.; Zhong, B.; de Boer, C.J.; Tabernero, J.; Calvo, E. Carlumab, an anti-C-C chemokine ligand 2 monoclonal antibody, in combination with four chemotherapy regimens for the treatment of patients with solid tumors: An open-label, multicenter phase 1b study. Target. Oncol. 2015, 10, 111-123. [CrossRef] [PubMed]

92. Sandhu, S.K.; Papadopoulos, K.; Fong, P.C.; Patnaik, A.; Messiou, C.; Olmos, D.; Wang, G.; Tromp, B.J.; Puchalski, T.A.; Balkwill, F.; et al. A first-in-human, first-in-class, phase I study of carlumab (CNTO 888), a human monoclonal antibody against CC-chemokine ligand 2 in patients with solid tumors. Cancer Chemother. Pharmacol. 2013, 71, 1041-1050. [CrossRef] [PubMed]

93. Pienta, K.J.; Machiels, J.P.; Schrijvers, D.; Alekseev, B.; Shkolnik, M.; Crabb, S.J.; Li, S.; Seetharam, S.; Puchalski, T.A.; Takimoto, C.; et al. Phase 2 study of carlumab (CNTO 888), a human monoclonal antibody against CC-chemokine ligand 2 (CCL2), in metastatic castration-resistant prostate cancer. Investig. New Drugs 2013, 31, 760-768. [CrossRef]

94. O'Hara, M.H.; Messersmith, W.; Kindler, H.; Zhang, W.; Pitou, C.; Szpurka, A.M.; Wang, D.; Peng, S.B.; Vangerow, B.; Khan, A.A.; et al. Safety and Pharmacokinetics of CXCR4 Peptide Antagonist, LY2510924, in Combination with Durvalumab in Advanced Refractory Solid Tumors. J. Pancreat. Cancer 2020, 6, 21-31. [CrossRef]

95. Bockorny, B.; Macarulla, T.; Semenisty, V.; Borazanci, E.; Feliu, J.; Ponz-Sarvise, M.; Abad, D.G.; Oberstein, P.; Alistar, A.; Muñoz, A.; et al. Motixafortide and Pembrolizumab Combined to Nanoliposomal Irinotecan, Fluorouracil, and Folinic Acid in Metastatic Pancreatic Cancer: The COMBAT/KEYNOTE-202 Trial. Clin. Cancer Res. 2021, 27, 5020-5027. [CrossRef] [PubMed]

96. Tap, W.D.; Gelderblom, H.; Palmerini, E.; Desai, J.; Bauer, S.; Blay, J.Y.; Alcindor, T.; Ganjoo, K.; Martín-Broto, J.; Ryan, C.W.; et al. Pexidartinib versus placebo for advanced tenosynovial giant cell tumour (ENLIVEN): A randomised phase 3 trial. Lancet 2019, 394, 478-487. [CrossRef]

97. Wesolowski, R.; Sharma, N.; Reebel, L.; Rodal, M.B.; Peck, A.; West, B.L.; Marimuthu, A.; Severson, P.; Karlin, D.A.; Dowlati, A.; et al. Phase Ib study of the combination of pexidartinib (PLX3397), a CSF-1R inhibitor, and paclitaxel in patients with advanced solid tumors. Ther. Adv. Med. Oncol. 2019, 11, 1758835919854238. [CrossRef]

98. Ries, C.H.; Cannarile, M.A.; Hoves, S.; Benz, J.; Wartha, K.; Runza, V.; Rey-Giraud, F.; Pradel, L.P.; Feuerhake, F.; Klaman, I.; et al. Targeting tumor-associated macrophages with anti-CSF-1R antibody reveals a strategy for cancer therapy. Cancer Cell 2014, 25, 846-859. [CrossRef]

99. Papadopoulos, K.P.; Gluck, L.; Martin, L.P.; Olszanski, A.J.; Tolcher, A.W.; Ngarmchamnanrith, G.; Rasmussen, E.; Amore, B.M.; Nagorsen, D.; Hill, J.S.; et al. First-in-Human Study of AMG 820, a Monoclonal Anti-Colony-Stimulating Factor 1 Receptor Antibody, in Patients with Advanced Solid Tumors. Clin. Cancer Res. 2017, 23, 5703-5710. [CrossRef]

100. Dowlati, A.; Harvey, R.D.; Carvajal, R.D.; Hamid, O.; Klempner, S.J.; Kauh, J.S.W.; Peterson, D.A.; Yu, D.; Chapman, S.C.; Szpurka, A.M.; et al. LY3022855, an anti-colony stimulating factor-1 receptor (CSF-1R) monoclonal antibody, in patients with advanced solid tumors refractory to standard therapy: Phase 1 dose-escalation trial. Investig. New Drugs 2021, 39, 1057-1071. [CrossRef]

101. Kuemmel, S.; Campone, M.; Loirat, D.; López López, R.; Beck, J.T.; De Laurentiis, M.; Im, S.A.; Kim, S.B.; Kwong, A.; Steger, G.G.; et al. A Randomized Phase II Study of Anti-CSF-1 Monoclonal Antibody Lacnotuzumab (MCS110) Combined with Gemcitabine and Carboplatin in Advanced Triple Negative Breast Cancer. Clin. Cancer Res. 2021. [CrossRef]

102. Adams, S.; Kozhaya, L.; Martiniuk, F.; Meng, T.C.; Chiriboga, L.; Liebes, L.; Hochman, T.; Shuman, N.; Axelrod, D.; Speyer, J.; et al. Topical TLR7 agonist imiquimod can induce immune-mediated rejection of skin metastases in patients with breast cancer. Clin. Cancer Res. 2012, 18, 6748-6757. [CrossRef] [PubMed]

103. Ferris, R.L.; Saba, N.F.; Gitlitz, B.J.; Haddad, R.; Sukari, A.; Neupane, P.; Morris, J.C.; Misiukiewicz, K.; Bauman, J.E.; Fenton, M.; et al. Effect of Adding Motolimod to Standard Combination Chemotherapy and Cetuximab Treatment of Patients With Squamous Cell Carcinoma of the Head and Neck: The Active8 Randomized Clinical Trial. JAMA Oncol. 2018, 4, 1583-1588. [CrossRef] 
104. O'Hara, M.H.; O’Reilly, E.M.; Varadhachary, G.; Wolff, R.A.; Wainberg, Z.A.; Ko, A.H.; Fisher, G.; Rahma, O.; Lyman, J.P.; Cabanski, C.R.; et al. CD40 agonistic monoclonal antibody APX005M (sotigalimab) and chemotherapy, with or without nivolumab, for the treatment of metastatic pancreatic adenocarcinoma: An open-label, multicentre, phase 1b study. Lancet Oncol. 2021, 22, 118-131. [CrossRef]

105. Sikic, B.I.; Lakhani, N.; Patnaik, A.; Shah, S.A.; Chandana, S.R.; Rasco, D.; Colevas, A.D.; O’Rourke, T.; Narayanan, S.; Papadopoulos, K.; et al. First-in-Human, First-in-Class Phase I Trial of the Anti-CD47 Antibody Hu5F9-G4 in Patients With Advanced Cancers. J. Clin. Oncol. 2019, 37, 946-953. [CrossRef]

106. Advani, R.; Flinn, I.; Popplewell, L.; Forero, A.; Bartlett, N.L.; Ghosh, N.; Kline, J.; Roschewski, M.; LaCasce, A.; Collins, G.P.; et al. CD47 Blockade by Hu5F9-G4 and Rituximab in Non-Hodgkin's Lymphoma. N. Engl. J. Med. 2018, 379, 1711-1721. [CrossRef]

107. Chang, A.L.; Miska, J.; Wainwright, D.A.; Dey, M.; Rivetta, C.V.; Yu, D.; Kanojia, D.; Pituch, K.C.; Qiao, J.; Pytel, P.; et al. CCL2 Produced by the Glioma Microenvironment Is Essential for the Recruitment of Regulatory T Cells and Myeloid-Derived Suppressor Cells. Cancer Res. 2016, 76, 5671-5682. [CrossRef]

108. Grossman, J.G.; Nywening, T.M.; Belt, B.A.; Panni, R.Z.; Krasnick, B.A.; DeNardo, D.G.; Hawkins, W.G.; Goedegebuure, S.P.; Linehan, D.C.; Fields, R.C. Recruitment of CCR2(+) tumor associated macrophage to sites of liver metastasis confers a poor prognosis in human colorectal cancer. Oncoimmunology 2018, 7, e1470729. [CrossRef] [PubMed]

109. Sanford, D.E.; Belt, B.A.; Panni, R.Z.; Mayer, A.; Deshpande, A.D.; Carpenter, D.; Mitchem, J.B.; Plambeck-Suess, S.M.; Worley, L.A.; Goetz, B.D.; et al. Inflammatory monocyte mobilization decreases patient survival in pancreatic cancer: A role for targeting the CCL2/CCR2 axis. Clin. Cancer Res. 2013, 19, 3404-3415. [CrossRef]

110. Lu, X.; Kang, Y. Chemokine (C-C motif) ligand 2 engages CCR2+ stromal cells of monocytic origin to promote breast cancer metastasis to lung and bone. J. Biol. Chem. 2009, 284, 29087-29096. [CrossRef] [PubMed]

111. Tu, M.M.; Abdel-Hafiz, H.A.; Jones, R.T.; Jean, A.; Hoff, K.J.; Duex, J.E.; Chauca-Diaz, A.; Costello, J.C.; Dancik, G.M.; Tamburini, B.A.J.; et al. Inhibition of the CCL2 receptor, CCR2, enhances tumor response to immune checkpoint therapy. Commun. Biol. 2020, 3, 720. [CrossRef] [PubMed]

112. Sánchez-Martín, L.; Estecha, A.; Samaniego, R.; Sánchez-Ramón, S.; Vega, M.Á.; Sánchez-Mateos, P. The chemokine CXCL12 regulates monocyte-macrophage differentiation and RUNX3 expression. Blood 2011, 117, 88-97. [CrossRef]

113. Scala, S. Molecular Pathways: Targeting the CXCR4-CXCL12 Axis-Untapped Potential in the Tumor Microenvironment. Clin. Cancer Res. 2015, 21, 4278-4285. [CrossRef]

114. Li, X.; Bu, W.; Meng, L.; Liu, X.; Wang, S.; Jiang, L.; Ren, M.; Fan, Y.; Sun, H. CXCL12/CXCR4 pathway orchestrates CSC-like properties by CAF recruited tumor associated macrophage in OSCC. Exp. Cell Res. 2019, 378, 131-138. [CrossRef] [PubMed]

115. Mota, J.M.; Leite, C.A.; Souza, L.E.; Melo, P.H.; Nascimento, D.C.; de-Deus-Wagatsuma, V.M.; Temporal, J.; Figueiredo, F.; Noushmehr, H.; Alves-Filho, J.C.; et al. Post-Sepsis State Induces Tumor-Associated Macrophage Accumulation through CXCR4/CXCL12 and Favors Tumor Progression in Mice. Cancer Immunol. Res. 2016, 4, 312-322. [CrossRef] [PubMed]

116. Zeng, Y.; Li, B.; Liang, Y.; Reeves, P.M.; Qu, X.; Ran, C.; Liu, Q.; Callahan, M.V.; Sluder, A.E.; Gelfand, J.A.; et al. Dual blockade of CXCL12-CXCR4 and PD-1-PD-L1 pathways prolongs survival of ovarian tumor-bearing mice by prevention of immunosuppression in the tumor microenvironment. FASEB J. 2019, 33, 6596-6608. [CrossRef]

117. Dupuy, A.G.; Caron, E. Integrin-dependent phagocytosis: Spreading from microadhesion to new concepts. J. Cell Sci. 2008, 121, 1773-1783. [CrossRef]

118. Ahn, G.O.; Tseng, D.; Liao, C.H.; Dorie, M.J.; Czechowicz, A.; Brown, J.M. Inhibition of Mac-1 (CD11b/CD18) enhances tumor response to radiation by reducing myeloid cell recruitment. Proc. Natl. Acad. Sci. USA 2010, 107, 8363-8368. [CrossRef]

119. Panni, R.Z.; Herndon, J.M.; Zuo, C.; Hegde, S.; Hogg, G.D.; Knolhoff, B.L.; Breden, M.A.; Li, X.; Krisnawan, V.E.; Khan, S.Q.; et al. Agonism of CD11b reprograms innate immunity to sensitize pancreatic cancer to immunotherapies. Sci. Transl. Med. $2019,11$. [CrossRef]

120. DeNardo, D.G.; Brennan, D.J.; Rexhepaj, E.; Ruffell, B.; Shiao, S.L.; Madden, S.F.; Gallagher, W.M.; Wadhwani, N.; Keil, S.D.; Junaid, S.A.; et al. Leukocyte Complexity Predicts Breast Cancer Survival and Functionally Regulates Response to Chemotherapy. Cancer Discov. 2011, 1, 54-67. [CrossRef]

121. Pyonteck, S.M.; Akkari, L.; Schuhmacher, A.J.; Bowman, R.L.; Sevenich, L.; Quail, D.F.; Olson, O.C.; Quick, M.L.; Huse, J.T.; Teijeiro, V.; et al. CSF-1R inhibition alters macrophage polarization and blocks glioma progression. Nat. Med. 2013, 19, 1264-1272. [CrossRef] [PubMed]

122. Strachan, D.C.; Ruffell, B.; Oei, Y.; Bissell, M.J.; Coussens, L.M.; Pryer, N.; Daniel, D. CSF1R inhibition delays cervical and mammary tumor growth in murine models by attenuating the turnover of tumor-associated macrophages and enhancing infiltration by CD8(+) T cells. Oncoimmunology 2013, 2, e26968. [CrossRef]

123. Zhang, C.; Ibrahim, P.N.; Zhang, J.; Burton, E.A.; Habets, G.; Zhang, Y.; Powell, B.; West, B.L.; Matusow, B.; Tsang, G.; et al. Design and pharmacology of a highly specific dual FMS and KIT kinase inhibitor. Proc. Natl. Acad. Sci. USA 2013, 110, 5689-5694. [CrossRef]

124. Mok, S.; Koya, R.C.; Tsui, C.; Xu, J.; Robert, L.; Wu, L.; Graeber, T.; West, B.L.; Bollag, G.; Ribas, A. Inhibition of CSF-1 receptor improves the antitumor efficacy of adoptive cell transfer immunotherapy. Cancer Res. 2014, 74, 153-161. [CrossRef] [PubMed]

125. Stafford, J.H.; Hirai, T.; Deng, L.; Chernikova, S.B.; Urata, K.; West, B.L.; Brown, J.M. Colony stimulating factor 1 receptor inhibition delays recurrence of glioblastoma after radiation by altering myeloid cell recruitment and polarization. Neuro Oncol. 2016, 18, 797-806. [CrossRef] 
126. Cannarile, M.A.; Weisser, M.; Jacob, W.; Jegg, A.M.; Ries, C.H.; Rüttinger, D. Colony-stimulating factor 1 receptor (CSF1R) inhibitors in cancer therapy. J. Immunother. Cancer 2017, 5, 53. [CrossRef]

127. Wang, N.; Liang, H.; Zen, K. Molecular mechanisms that influence the macrophage m1-m2 polarization balance. Front. Immunol. 2014, 5, 614. [CrossRef]

128. Singh, M.; Khong, H.; Dai, Z.; Huang, X.F.; Wargo, J.A.; Cooper, Z.A.; Vasilakos, J.P.; Hwu, P.; Overwijk, W.W. Effective innate and adaptive antimelanoma immunity through localized TLR7/8 activation. J. Immunol. 2014, 193, 4722-4731. [CrossRef]

129. Elgueta, R.; Benson, M.J.; de Vries, V.C.; Wasiuk, A.; Guo, Y.; Noelle, R.J. Molecular mechanism and function of CD40/CD40L engagement in the immune system. Immunol. Rev. 2009, 229, 152-172. [CrossRef]

130. Vonderheide, R.H. CD40 Agonist Antibodies in Cancer Immunotherapy. Annu. Rev. Med. 2020, 71, 47-58. [CrossRef] [PubMed]

131. Yang, Y.; Wilson, J.M. CD40 ligand-dependent T cell activation: Requirement of B7-CD28 signaling through CD40. Science 1996, 273, 1862-1864. [CrossRef] [PubMed]

132. Stromnes, I.M.; Burrack, A.L.; Hulbert, A.; Bonson, P.; Black, C.; Brockenbrough, J.S.; Raynor, J.F.; Spartz, E.J.; Pierce, R.H.; Greenberg, P.D.; et al. Differential Effects of Depleting versus Programming Tumor-Associated Macrophages on Engineered T Cells in Pancreatic Ductal Adenocarcinoma. Cancer Immunol. Res. 2019, 7, 977-989. [CrossRef] [PubMed]

133. Beatty, G.L.; Chiorean, E.G.; Fishman, M.P.; Saboury, B.; Teitelbaum, U.R.; Sun, W.; Huhn, R.D.; Song, W.; Li, D.; Sharp, L.L.; et al. CD40 agonists alter tumor stroma and show efficacy against pancreatic carcinoma in mice and humans. Science 2011, 331, 1612-1616. [CrossRef]

134. Perry, C.J.; Muñoz-Rojas, A.R.; Meeth, K.M.; Kellman, L.N.; Amezquita, R.A.; Thakral, D.; Du, V.Y.; Wang, J.X.; Damsky, W.; Kuhlmann, A.L.; et al. Myeloid-targeted immunotherapies act in synergy to induce inflammation and antitumor immunity. J. Exp. Med. 2018, 215, 877-893. [CrossRef]

135. Diggs, L.P.; Ruf, B.; Ma, C.; Heinrich, B.; Cui, L.; Zhang, Q.; McVey, J.C.; Wabitsch, S.; Heinrich, S.; Rosato, U.; et al. CD40-mediated immune cell activation enhances response to anti-PD-1 in murine intrahepatic cholangiocarcinoma. J. Hepatol. 2021, 74, 1145-1154. [CrossRef] [PubMed]

136. Wang, T.; Zhang, J.; Hou, T.; Yin, X.; Zhang, N. Selective targeting of tumor cells and tumor associated macrophages separately by twin-like core-shell nanoparticles for enhanced tumor-localized chemoimmunotherapy. Nanoscale 2019, 11, 13934-13946. [CrossRef]

137. Jaynes, J.M.; Sable, R.; Ronzetti, M.; Bautista, W.; Knotts, Z.; Abisoye-Ogunniyan, A.; Li, D.; Calvo, R.; Dashnyam, M.; Singh, A.; et al. Mannose receptor (CD206) activation in tumor-associated macrophages enhances adaptive and innate antitumor immune responses. Sci. Transl. Med. 2020, 12. [CrossRef]

138. Wang, W.; Marinis, J.M.; Beal, A.M.; Savadkar, S.; Wu, Y.; Khan, M.; Taunk, P.S.; Wu, N.; Su, W.; Wu, J.; et al. RIP1 Kinase Drives Macrophage-Mediated Adaptive Immune Tolerance in Pancreatic Cancer. Cancer Cell 2018, 34, 757-774.e757. [CrossRef]

139. Kaneda, M.M.; Cappello, P.; Nguyen, A.V.; Ralainirina, N.; Hardamon, C.R.; Foubert, P.; Schmid, M.C.; Sun, P.; Mose, E.; Bouvet, M.; et al. Macrophage PI3K $\gamma$ Drives Pancreatic Ductal Adenocarcinoma Progression. Cancer Discov. 2016, 6, 870-885. [CrossRef]

140. Kaneda, M.M.; Messer, K.S.; Ralainirina, N.; Li, H.; Leem, C.J.; Gorjestani, S.; Woo, G.; Nguyen, A.V.; Figueiredo, C.C.; Foubert, P.; et al. PI3K $\gamma$ is a molecular switch that controls immune suppression. Nature 2016, 539, 437-442. [CrossRef]

141. Xue, X.; Huang, Y.; Bo, R.; Jia, B.; Wu, H.; Yuan, Y.; Wang, Z.; Ma, Z.; Jing, D.; Xu, X.; et al. Trojan Horse nanotheranostics with dual transformability and multifunctionality for highly effective cancer treatment. Nat. Commun. 2018, 9, 3653. [CrossRef] [PubMed]

142. Vinogradov, S.; Warren, G.; Wei, X. Macrophages associated with tumors as potential targets and therapeutic intermediates. Nanomedicine 2014, 9, 695-707. [CrossRef] [PubMed]

143. Yang, H.; Shao, R.; Huang, H.; Wang, X.; Rong, Z.; Lin, Y. Engineering macrophages to phagocytose cancer cells by blocking the CD47/SIRPa axis. Cancer Med. 2019, 8, 4245-4253. [CrossRef]

144. Weiskopf, K.; Jahchan, N.S.; Schnorr, P.J.; Cristea, S.; Ring, A.M.; Maute, R.L.; Volkmer, A.K.; Volkmer, J.P.; Liu, J.; Lim, J.S.; et al. CD47-blocking immunotherapies stimulate macrophage-mediated destruction of small-cell lung cancer. J. Clin. Investig. 2016, 126, 2610-2620. [CrossRef] [PubMed]

145. Gholamin, S.; Mitra, S.S.; Feroze, A.H.; Liu, J.; Kahn, S.A.; Zhang, M.; Esparza, R.; Richard, C.; Ramaswamy, V.; Remke, M.; et al. Disrupting the CD47-SIRP $\alpha$ anti-phagocytic axis by a humanized anti-CD47 antibody is an efficacious treatment for malignant pediatric brain tumors. Sci. Transl. Med. 2017, 9, eaaf2968. [CrossRef]

146. Upton, R.; Banuelos, A.; Feng, D.; Biswas, T.; Kao, K.; McKenna, K.; Willingham, S.; Ho, P.Y.; Rosental, B.; Tal, M.C.; et al. Combining CD47 blockade with trastuzumab eliminates HER2-positive breast cancer cells and overcomes trastuzumab tolerance. Proc. Natl. Acad. Sci. USA 2021, 118. [CrossRef] [PubMed]

147. Petrova, P.S.; Viller, N.N.; Wong, M.; Pang, X.; Lin, G.H.; Dodge, K.; Chai, V.; Chen, H.; Lee, V.; House, V.; et al. TTI-621 (SIRP $\alpha$ Fc): A CD47-Blocking Innate Immune Checkpoint Inhibitor with Broad Antitumor Activity and Minimal Erythrocyte Binding. Clin. Cancer Res. 2017, 23, 1068-1079. [CrossRef]

148. Barkal, A.A.; Weiskopf, K.; Kao, K.S.; Gordon, S.R.; Rosental, B.; Yiu, Y.Y.; George, B.M.; Markovic, M.; Ring, N.G.; Tsai, J.M.; et al. Engagement of MHC class I by the inhibitory receptor LILRB1 suppresses macrophages and is a target of cancer immunotherapy. Nat. Immunol. 2018, 19, 76-84. [CrossRef] 
149. Lu, L.C.; Lee, Y.H.; Chang, C.J.; Shun, C.T.; Fang, C.Y.; Shao, Y.Y.; Liu, T.H.; Cheng, A.L.; Hsu, C.H. Increased Expression of Programmed Death-Ligand 1 in Infiltrating Immune Cells in Hepatocellular Carcinoma Tissues after Sorafenib Treatment. Liver Cancer 2019, 8, 110-120. [CrossRef]

150. Bellmunt, J.; Mullane, S.A.; Werner, L.; Fay, A.P.; Callea, M.; Leow, J.J.; Taplin, M.E.; Choueiri, T.K.; Hodi, F.S.; Freeman, G.J.; et al. Association of PD-L1 expression on tumor-infiltrating mononuclear cells and overall survival in patients with urothelial carcinoma. Ann. Oncol. 2015, 26, 812-817. [CrossRef]

151. Hatogai, K.; Kitano, S.; Fujii, S.; Kojima, T.; Daiko, H.; Nomura, S.; Yoshino, T.; Ohtsu, A.; Takiguchi, Y.; Doi, T.; et al. Comprehensive immunohistochemical analysis of tumor microenvironment immune status in esophageal squamous cell carcinoma. Oncotarget 2016, 7, 47252-47264. [CrossRef] [PubMed] 